\title{
Lagrangian circulation on the Southeast U.S. Continental Shelf: implications for larval dispersal and retention
}

\author{
K. P. Edwards ${ }^{\text {a, }}$, J.A. Hare ${ }^{\text {b,c }}$, F.E. Werner ${ }^{\mathrm{a}}$ and B.O. Blanton ${ }^{\mathrm{a}}$ \\ ${ }^{a}$ University of North Carolina at Chapel Hill, Chapel Hill, NC 27599-3300, USA \\ ${ }^{\mathrm{b}}$ NOAA NOS NCCOS, Center for Coastal Fisheries and Habitat Research, Beaufort, NC \\ 28516
}

${ }^{\mathrm{c}}$ NOAA NMFS NEFSC, Narragansett Laboratory, Narragansett, RI 02882

\begin{abstract}
Lagrangian characterization of continental shelf circulation provides estimates of the retention and transport of particulate and dissolved substances. In this paper, we quantify the retentive characteristics of the Southeast U.S. Continental Shelf by comparing observed and numerical (modeled) drifters released throughout 2000 and 2001. Agreement between the observed and computed drifter trajectories shows that retention on this shelf can be up to two months at any point during the year. These results have important implications for ecological and fisheries applications and indicate that the populations of marine organisms in this region might be relatively closed (i.e., with weak exchange) during some periods of the year.
\end{abstract}

* Corresponding author. Tel.: +1-919-962-4466; Fax: +1-919-962-1254

Email address: kpedwards@unc. edu (K. P. Edwards). 


\section{Introduction}

Quantitative understanding of the fate and transport of particulate and dissolved substances on continental shelves worldwide is a subject of intense study. Understanding larval dispersal for the design of marine protected areas (Roberts, 1997; Lockwood et al., 2002; Palumbi, 2003; Shanks et al., 2003), studying the dispersion of discharged ballast ship water (Larson et al., 2003), effective search and rescue efforts, tracking the fate of oil spills and other pollutants (Spaulding et al., 1994; Aliani et al., 2003), all depend on our ability to predict the Lagrangian trajectories of the substances involved. In this paper, we focus on the Lagrangian characterization of the Southeast U.S. Continental Shelf (SEUSCS).

The SEUSCS has been studied extensively (Boicourt et al., 1998; Blanton et al., 2003, and references therein). It extends from Cape Canaveral, Florida to Cape Hatteras, North Carolina. The shelf is narrowest at the northern and southern ends $(10-30 \mathrm{~km})$ and widest in the center, off the Georgia coast $(120 \mathrm{~km})$ (Figure 1). The isobaths are largely parallel to the coast, which is punctuated with rivers and tidal inlets, particularly between South Carolina and northern Florida. The shelf waters (shoreward of the $100-\mathrm{m}$ isobath) are significantly influenced by atmospheric fluxes, buoyancy fluxes from rivers, tides, and the Gulf Stream (Lee et al., 1981; Lee and Atkinson, 1983; Oey et al., 1987). In the cross-shelf direction, the shelf can be divided into inner-, mid- and outer-shelf regions, each with a primary driving mechanism (Boicourt et al., 1998). The inner-shelf (from the coast to the 20-m isobath) is dominated by river discharge, atmospheric fluxes and tides; the mid-shelf (roughly the 20- to $45-\mathrm{m}$ isobaths) is driven primarily by the winds but is also influenced by the tides with frequent contributions by the Gulf Stream; the outer-shelf is dominated by the Gulf Stream (Lee et al., 1991). 
The effect of the Gulf Stream on the shelf waters varies strongly with latitude. Lee et al. (1991) identify two regions in the SAB, the narrow regions north of Cape Canaveral and north of the Charleston Bump that support amplification in the Gulf Stream meanders and eddies with dissipation of these features occurring between the two regions on the Georgia shelf. During the summer, the generally upwelling favorable winds on the shelf combined with Gulf Stream eddy-induced upwelling can extend the upwelled subsurface water to mid- or inner-shelf regions. More recently Aretxabaleta et al. (accepted) has documented interannual variability in bottom water temperature on the shelf that may be associated with transport variations in the Gulf Stream. The drifters, in this study, were released off the Georgia coast in the widest part of the shelf. The Gulf Stream effects in this region are intermittent in the mid- and inner-shelf (Lee et al., 1991).

The circulation on the inner- and mid- shelf changes seasonally with the winds. During the winter months (November-February), mean winds are southward to southeastward. Spring (March-May) is a transition period with winds rotating towards the north in the central and northern southeast U.S. continental shelf, while winds in the central and south Florida coast are westward. Summer (June-July) winds are generally along-shelf to the northeast, while August appears to be a transition month during which mean winds are weak. Autumn (September-October) winds are primarily southwestward, along-shelf over the northern part of the shelf and cross-shelf over the southern section (Weber and Blanton, 1980; Blanton et al., 1985, 2003).

Although physical circulation processes on the shelf are well described, the Lagrangian characteristics of the southeast U.S. continental shelf- important to estimates of the transport of particulate and dissolved subtances - have not been defined. Some studies exist for the northern part of the shelf (Glenn and Ebbesmeyer, 
1994; Quinlan et al., 1999; Werner et al., 1999; Hare et al., 2002), and in the vicinity of inlets (Churchill et al., 1999), but these have been usually of short (week long) duration and do not include central and southern portions of the system. In this study we consider the Lagrangian circulation over periods of up to two months based on observed drifter trajectories and modeled flow fields. To our knowledge, there are no other studies in the SEUSCS that have attempted to quantify the shelf's Lagrangian circulation over such time scales, that are directly relevant to ecological and fisheries sciences.

\subsection{Lagrangian flow characterization: a review of physical and ecological con- siderations}

Three-dimensional (3-D) numerical modeling incorporating Lagrangian particle tracking has become an important tool in coastal and fisheries oceanography (Werner et al., 2001; Mariano et al., 2002), and has been used for a wide variety of applications including: describing physical circulation characteristics (Werner et al., 1999; Yang et al., 1999; Naimie et al., 2001), modeling oil spills and the spread of other pollutants (Spaulding et al., 1994; Aliani et al., 2003), studying the dispersion of discharged ship ballast water (Larson et al., 2003) and studying biologicalphysical interactions (Bartsch et al., 1989; Werner et al., 1993b; Hermann et al., 1996; Stegmann et al., 1999).

The use of Lagrangian data has a long history and has primarily been used by oceanographers for estimation of mean flows in the oceans and marginal seas (Mariano et al., 2002). In 1785, Benjamin Franklin made early current measurements from anchored ships using visually tracked buoys and, in the 1940's, Stommel used aerial photography of floating sheets of paper to observe oceanic turbulence 
(Davis, 1991). Drift bottles and cards with requests for notification of discovery allowed larger-scale observation of circulation patterns but only provided beginning and ending points with no details of the path taken (Davis, 1991). Technological improvements, such as radar- and satellite-tracked near surface drifters and the invention of the subsurface Swallow, SOFAR and RAFOS floats, and new data sets spanning a vast range of geographical locations have allowed tracking of both largeor basin-scale ocean currents, important for climate studies, and small-scale coastal observations, and have greatly expanded knowledge of oceanic processes (Davis, 1991; Mariano et al., 2002).

While many of the drifter studies have taken place in the deep ocean basins, Lagrangian drifters have been used in the coastal oceans around the world (Davis, 1985; Haynes and Barton, 1991; Paduan and Niiler, 1990; Limeburner and Beardsley, 1996; van Aken, 2002; Tseng and Shen, 2003). In one early study, radar-tracked drifters were used to map a surface eddy off of northern Baja California (Reid et al., 1963). In the 1980's, the Coastal Ocean Dynamics Experiment (CODE) off northern California used drifters to study coastal eddies, jets and squirts which carried nearshore drifters more than $100 \mathrm{~km}$ offshore in just a few days (Davis, 1985, 1991). Drifters released in the Iberian coastal transition zone were gradually carried northward between September 1986 and March 1987 in trajectories which revealed the presence of numerous mesoscale eddies and was used to estimate the rate of dispersion and Lagrangian integral time scales (Haynes and Barton, 1991). In the California coastal transition zone, drifters used to study motion in cold-water features identified by satellite AVHRR imagery confirmed the presence of strong ( $>50 \mathrm{~cm} \mathrm{~s}^{-1}$ ) along-axis flow (Paduan and Niiler, 1990).

Between 1991 and 1993, drifters released in the Greenland, Iceland and Norwegian Seas were used to compose the first basin-scale, accurate near-surface velocity set 
of the Nordic Seas (Poulain et al., 1996). The drifter movements confirmed the general cyclonic gyre circulation in the Nordic seas and indicated smaller cyclonic circulation patterns in all the major sub-basins. In the Adriatic Sea, the data from over 200 satellite-tracked drifters that were deployed over a $10 \mathrm{yr}$ period was used to study the surface circulation (Poulain, 1999, 2001). Seasonal maps of mean velocity show three distinct recirculation cells in the northern, central and southern subbasins. The drifter data was also used to compute subtidal velocity variance and mean kinetic energy.

A recent study on the West Florida Shelf combines the results of drift-bottle studies in the 1960's, satellite tracked surface drifters released in 1996 and 1997 and the results of a circulation model to describe the Lagrangian circulation on the shelf (Yang et al., 1999). Lagrangian drifters were used as part of the U.S. GLOBEC Georges Bank program to study the geographic and seasonal patterns of nearsurface circulation (Naimie et al., 2001) and the smaller-scale circulation around the tidal front (Manning et al., 2001; Aretxabaleta et al., 2005). Moving south to the Middle Atlantic Bight, surface and seabed drifters were used to study the subtidal circulation in Delaware Bay and the adjacent continental shelf (Stefánsson et al., 1971; Pape and Garvine, 1982). More recently, Lozier and Gawarkiewicz (2001) studied cross-frontal exchange characteristics using surface drifters in the Middle Atlantic Bight. In 1974 and 1975, drift bottles containing preaddressed return cards were used to study the circulation on the continental shelf south of Cape Lookout, North Carolina (Barans and Roumillat, 1978). As part of the Frontal Eddy Dynamics (FRED) experiment, satellite-tracked drifters were used to characterize the structure and propagation of Eddy Abbott between Capes Fear and Hatteras, North Carolina (Glenn and Ebbesmeyer, 1994). On a smaller scale, Lagrangian drifters have been used to study the flood tide circulation carrying water through Beaufort 
Inlet, North Carolina (Churchill et al., 1999).

From an ecological perspective, Lagrangian particle tracking may also be used to study one of the most pressing issues in fisheries oceanography: the extent of larval dispersal which may define open versus closed populations (Cowen et al., 2002). An open population receives recruiting larvae from those spawned in other locations, while a closed population receives recruiting larvae primarily from local spawning activity (Mora and Sale, 2002). Many marine populations are thought to be connected over large distances by pelagic larval dispersal (Caley et al., 1996; Roberts, 1997). The extent of larval dispersal has traditionally been estimated from the duration of the pelagic larval stage combined with the movement of passive particles in low-frequency currents (Grantham et al. (2003); Shanks et al. (2003) and references therein). Additionally, the analysis of DNA among locations has indicated substantial gene flow (e.g., larval dispersal in marine populations, see Kinlan and Gaines, 2003; Palumbi, 2003), supporting the idea of large-scale dispersal of larvae. However, there is growing evidence that larval dispersal may be limited to shorter spatial scales than previously thought (Cowen et al., 2002) indicating that marine populations may be more closed than open, and that the importance of local processes local fisheries may have been underestimated (Cowen et al., 2000; Mora and Sale, 2002).

Three-dimensional numerical models with Lagrangian particle tracking have also been widely used to study biological-physical interactions including the transport of planktonic larvae and the connectivity of populations. For example, the advection of passive particles (with no behavior) at multiple depths was used to study concentrations of cod larvae at a frontal zone on Georges Bank (Manning et al., 2001). Drifters released in the Gulf of Mexico were used to study possible patterns of larval dispersal (Lugo-Fernández et al., 2001). Another study varied the particle 
release location (in 3 dimensions), time and buoyancy to determine the transport success of anchovy eggs from spawning locations to nursery grounds in the southern Benguela region (Parada et al., 2003). Lagrangian calculations were used to examine the processes and pathways that connect spawning areas, nursery grounds and feeding areas for krill in the Southern Ocean (Capella et al., 1992). Lagrangian drifters from coastal studies between 1987 and 1996 were used to study the possible routes of larval fish transport from south of Cape Hatteras to north of Cape Hatteras on the U.S. continental shelf (Hare et al., 2002).

Some studies have assigned behavior to the particles as they are advected within the circulation field. Diel vertical behavior was assigned to menhaden and spot larvae when investigating the transport pathways from offshore spawning grounds to estuarine nursery habitats (Hare et al., 1999), while effects of horizontal swimming behavior were considered by Werner et al. (1993b) in a study of larval cod and haddock on Georges Bank and by Yeung and Lee (2002) in a study of spiny lobster. In addition, some studies coupled individual-based trophodynamic models with the circulation and particle tracking models (Werner et al., 1996, 2001; Pedersen et al., 2003) to follow the feeding and growth of individual larvae through their planktonic stage.

As these biological-physical models grow in application and complexity, it is necessary to evaluate how well they compare to actual data and to define the conditions during which the comparisons do not work well (Lynch et al., 2001). Model validation, or skill assessment, is difficult and typically done through comparisons with Eulerian observations (Blanton, 2003). However, the comparison of observed and modeled Lagrangian data is also a useful method to verify model flow fields, providing at the same time direct observations of water parcel (or drifter) movement and potential transport pathways. 
This study is part of a larger effort in the development of Marine Protected Areas (MPAs) on the southeast U.S. continental shelf. One of the main ways that MPAs are thought to enhance fisheries is through the dispersal of larvae to fished areas (Guénette et al., 1998; Crowder et al., 2000). As a step toward modeling larval fish dispersal on this shelf ecosystem, this paper provides a baseline validation for the model flow fields and a comparison between observed and numerical drifters. To simulate the drifters, we have used a 3-D numerical model for the shelf combined with Lagrangian particle tracking.

Lagrangian measurements of oceanic flows generally cannot appropriately sample all relevant space and time-scales. Additionally, sensitivity to initial location and time of release are known to affect drifter trajectories. On certain continental shelves, due to strong topographic steering, some of the known issues of undersampling are perhaps lessened. While we acknowledge that releasing more drifters would improve our estimates, we implicitly assume that the number of drifters available to us in this study adequately (and at least qualitatively) capture the main features of the transport on the shelf during the various releases.

\section{Circulation Model}

The circulation model used is described in Lynch and Werner (1991) and Lynch et al. (1996). The model is a free-surface 3-D finite element time-stepping model of the shallow-water equations with conventional Boussinesq and hydrostatic assumptions. It uses terrain-following vertical coordinates configured to resolve both surface and bottom boundary layers. The model is fully nonlinear and solves prognostically for the evolution of the density field (Lynch et al., 1996; Aretxabaleta et al., 2005). In the application herein, however, we have not included stratification 
effects.

The model domain extends from south of Cape Canaveral, Florida to Cape Fear, North Carolina (Figure 1). The model grid contains 9606 nodes, 18,691 elements and has 21 vertical levels and was run with a minumum bathymetric depth of $2 \mathrm{~m}$. Grid spacing is variable with the smallest grid spacing of order $1 \mathrm{~km}$ nearest the coast increasing off-shore to order $10 \mathrm{~km}$. The model time-step is $60 \mathrm{~s}$ with a full 3-D output saved every hour to compute the Lagrangian trajectories using the algorithm described in Blanton (1993) enhanced to account for drifter slippage as in Edwards et al. (accepted).

The circulation model was forced by wind stress and tides. The model boundary conditions are specified with tidal amplitudes and phases as explained below. No radiation boundary conditions or through-flow conditions are imposed. In a climatological study of the domain, Blanton et al. (2003) found that the monthly baroclinic alongshore flows on the shelf were weak, on the order of $1-5 \mathrm{cms}^{-1}$. We did not include these, or other far-field effects, in the imposed boundary conditions, which suggests possible over or underestimates of our results of that order. The wind field was obtained from the National Centers for Environmental Prediction (NCEP) Eta Data Assimilation System (EDAS). The EDAS atmospheric forcing fields are provided at a $32 \mathrm{~km}$ resolution and at $3 \mathrm{~h}$ intervals. Surface flux fields are extracted and interpolated onto the grid. For input into the model, the $10 \mathrm{~m}$ wind fields are then converted to wind stress as in Large and Pond (1981).

Tidal elevations for the $M_{2}, N_{2}, S_{2}, O_{1}, K_{1}, Q_{1}, P_{1}$, and $K_{2}$ constituents are applied on the open boundary (see Blanton et al., 2004 for details). Based on a harmonic analysis from the South Atlantic Bight Synoptic Offshore Observational Network (SABSOON) Tower R2 water level record, these represent the largest 
semi-diurnal and diurnal midshelf constituents (Blanton et al., 2004). We include $Q_{1}, P_{1}$, and $K_{2}$ for consistency with other modelling projects.

\section{Eulerian Data and Model Results}

Eulerian comparisons between available data and model output were made for the period when Lagrangian data were available. Hourly observations from SABSOON Tower R6 (Seim, 2000) and the National Ocean Service (NOS) water level measurements at Fort Pulaski, Georgia and St. Augustine, Florida (see Figure 1) are used to compare with model results. Observations from the SABSOON towers include ADCP measurements at the R6 tower and temperature and salinity measurements at the R2 tower during our study period. Wind observations from the Grays Reef National Marine Sanctuary (GRNMS) NDBC buoy were downloaded hourly and are used to compare with the EDAS wind field used by the circulation model. A rotation angle of $31^{\circ}$ clockwise from true north was used at the R6 Tower to obtain the along-shelf and cross-shelf currents. A negative along-shelf velocity indicates flow along-shelf to the south while a negative cross-shelf velocity indicates on-shelf flow. The statistics used here as an analysis of the model skill include the root mean square (rms) of the misfit (model results minus observations) and the correlation coefficient between the model results and observations.

For most of the study period, the daily discharge of rivers onto the southeast U.S continental shelf was below the long-term month average (Figure 2). However, most of the rivers had a large discharge in late-March or early-April 2001. The Savannah River, Pee Dee River and Cape Fear Rivers also had larger than average discharges in late-September or early-October 2000. Stratification was generally low during the study period (Figure 3). While there was only surface data available 
for much of October 2000 at the R2 tower, CTD data from the cruise deploying the drifters does not show stratification. During the drifter release periods, the biggest stratification event at R2 is from 10 April 2001 onward.

The analysis of model skill has been separated into frequency bands with most of the variability contained at tidal frequencies ( 0.88 cycles per day (c.p.d.) and higher or periods of $27 \mathrm{~h}$ and shorter). The tidal analysis includes the diurnal $\left(O_{1}\right.$, $K_{1}, Q_{1}$ and $\left.P_{1}\right)$ and semi-diurnal $\left(M_{2}, N_{2}, S_{2}\right.$ and $\left.K_{2}\right)$ tides. The tides account for about $95 \%$ of the total signal variance in the water level records and about $89 \%$ (67\%) of the cross-shelf (and along-shelf) depth-averaged velocity components on the mid-shelf at the SABSOON Towers (Blanton et al., 2004).

Weather-band responses are generally subtidal and associated with the passage of atmospheric fronts on timescales of $2-15$ days (0.5 to 0.067 c.p.d.). The model results and observations are low-pass filtered at $40 \mathrm{~h}$ to isolate the weather-band processes. Comparisons have been made of both coastal water levels and currents on the shelf (Figures 7 through 12 (c and e)).

Model results show good agreement with demeaned water level measurements at Ft. Pulaski and St. Augustine (Table 1, Figures 7 through 12). The demeaned water level misfit ranges between $0.04 \mathrm{~m}$ and $0.08 \mathrm{~m}$ with the largest misfits in June 2000 at both locations. Model results also agreed well with along-shelf currents but less well with cross-shelf currents (Table 2, Figures 7 through 12): the velocity misfit ranges between $0.042 \mathrm{~m} \mathrm{~s}^{-1}$ and $0.14 \mathrm{~m} \mathrm{~s}^{-1}$ with a maximum in the along-shelf direction in June 2000.

The misfit between the EDAS and observed wind fields (Table 3) is one source of misfit between the model results and observations. The winds have been rotated (also $31^{\circ}$ clockwise from true north) into across- and along-shelf components with 
the rms misfit calculated for the modeled drifter periods. The rms misfit in the wind field varies from 0.020 to $0.032 \mathrm{~Pa}$ with the maximum in the along-shelf wind in October 2000 and the minimum in the cross-shelf wind also in October 2000. With a high correlation coefficient in the along-shelf direction in October 2000, the high rms misfit suggests that the EDAS model winds missed the peaks in observed winds but captured the overall wind pattern.

\section{Lagrangian Data and Model Results}

Lagrangian comparisons were made with fifteen drifters that were released in the vicinity of Grays Reef National Marine Sanctuary (GRNMS) near the middle of the southeast U.S continental shelf between April 2000 and March 2001 (Figure 1 and Table 4). While the estimated path-length of most of the drifters approached or exceeded 1,000 km (Table 4), only two of the fifteen drifters were advected off of the shelf possibly through entrainment in the Gulf Stream.

The drifters were WOCE SVP holey sock drifters drogued at a depth of 10 meters. The drogues were $6 \mathrm{~m}$ long and $1 \mathrm{~m}$ in diameter with spherical floats either 13.5 inches or 16 inches in diameter. Due to the size and depth of the drogues, any drifters moving into water shallower than $15 \mathrm{~m}$ are assumed to drag on the bottom and the model comparison is stopped. This occurred only twice: drifter 26723 released on June 21 and drifter 30374 released on October 3. The data used here is the error-checked raw data as reported by ARGOS (not interpolated to regular time intervals).

While the drifters are designed to measure Lagrangian water parcel trajectories at the drogue depth, it is important to realize that they do not provide a true description 
of the circulation. Drifters slip from true motion due to several factors, including: drag on both the tether and drogue induced by shear currents, wind drag on the float, and wave rectification (Geyer, 1989; Edwards et al., accepted). Because they are not neutrally buoyant, the drifters follow a specific depth in the ocean rather than true 3D flow of water particles.

The numerical drifters were tracked hourly through the 3-D flow field starting at the time and location of the first satellite record from the observed drifters and were tracked for approximately one month. Small scale (sub-grid-scale) motions arising from frontal instabilities, sea breezes, etc., may also affect the observed drifter trajectories. We experimented computing ensemble numerical drifter trajectories subjected to random kicks resulting from diffusivities of $1-10 \mathrm{~m}^{2} \mathrm{~s}^{-1}$ and found no significant differences in the computed drifter solutions. Because we are trying to model the WOCE holey sock drifters, the numerical drifter paths included a correction for the difference between EDAS and observed wind stress combined with drifter slippage (Edwards et al., accepted). The numerical drifters were kept at $10-\mathrm{m}$ depth to match the mid-depth of the drogues released in the field and their trajectories were then sampled at the reporting times of the observed drifters for analysis and plotting purposes.

Overall, the numerical and observed drifter tracks were in good agreement. A linear regression for all fifteen drifter releases gives a separation rate of $2.0 \mathrm{~km} \mathrm{~d}^{-1}$ with an r-square value of 0.48 . The regression, excluding the June 2000 drifters which yielded the poorest agreement, produces a slope of $1.7 \mathrm{~km} \mathrm{~d}^{-1}$ (less than $2 \mathrm{~cm} \mathrm{~s}^{-1}$ ) with an r-square value of 0.89 (Table 5, Figure 5).

The results from each of the five release periods are discussed in further detail below and summarized in Table 5. Each section provides a comparison between 
drifter movement and the separation between the observed and numerical drifters (along-shelf and cross-shelf) with the wind regime and the results of the 3D circulation model. A linear interpolation of a rotation angle based on the position of the numerical drifter was used to split the separation distance (observed minus numerical) into along- and cross-shelf components. At $31^{\circ} \mathrm{N}$ (and the R6 Tower) this rotation angle was $31^{\circ}$ clockwise from true north and at $32^{\circ} \mathrm{N}$ the rotation angle was $45^{\circ}$ clockwise from true north. A negative separation distance in the along-shelf indicates that the observed drifters are along-shelf to the south of the numerical drifters while a positive along-shelf separation distance indicates that the observed drifters are to the north of the numerical drifters. In the cross-shelf direction, a negative separation distance indicates that the observed drifter is closer to shore than the numerical drifter. The total separation distance is always positive and is equal to the square root of the summed squares of the along- and cross- shelf separation distances.

\subsection{April 2000 releases}

April 2000 provides the best comparison between the numerical and observed drifter trajectories with an average separation rate of $1.2 \mathrm{~km} \mathrm{~d}^{-1}$. For this release date, the average net displacement of the observed drifters after one month was $80 \mathrm{~km}$ (Figure 6, Table 5). The observed drifters had a large cross-shelf component that was not seen in the numerical drifters. However, the along-shelf motion of the modeled and observed drifters was essentially the same. Throughout the period, most of the separation is in the cross-shelf direction with a gradual increase in the along-shelf separation (Figure 7).

The winds during the April 2000 release period are generally along-shelf towards 
the north with an average speed of 7.1 $\mathrm{m} \mathrm{s}^{-1}$. From 15-19 May, the winds were mostly along-shelf but rotated from the north to the south. During this time, the observed drifters travelled farther than the numerical drifters, and the observed drifters moved from north to south of the numerical drifters (Figure 6). During this period, the change in separation distance per day was greatest when the magnitude and direction of the EDAS winds underestimated observed winds at GRNMS. The 3D circulation model results, for the same time period, underestimate both the coastal water level and the along- and cross-shelf velocity at the R6 Tower.

\subsection{June 2000 releases}

June 2000 had the least favorable comparison between the numerical and observed drifter tracks. Both observed and numerical drifters were carried along-shelf to the north-east with the observed drifters traveling farther: an average of $177 \mathrm{~km}$ for the observed drifters and $70 \mathrm{~km}$ for the numerical drifters (Figure 6, Table 5). The separation rate was $4.8 \mathrm{~km} \mathrm{day}^{-1}$ (Table 5). The separation distance was almost entirely in the along-shelf direction for most of the period with a slight increase in the cross-shelf separation at the end of the month as the remaining drifter moved cross-shelf and crossed the $25 \mathrm{~m}$ isobath (Figure 8).

The winds during the June drifter release period were generally upwelling favorable to the north-east. Drifter separation distances improved slightly during wind relaxation or reversals around the 1st, 8th and 15th of July (Figure 8). Both the low-passed along-shelf model velocity and water levels were underestimate the observations (Figure 8c and d). The underestimation of the drifter movement during this time period may be due to several factors not explicitly included in our modelled flows: stratification and the upwelling favorable winds may combine to cre- 
ate strong northward and offshore transport in jetlike flow regions within the river plume (Kourafalou et al., 1996b).

\subsection{October 2000 releases}

After release, numerical and observed drifters moved southward along the shelf (Figure 6. The average net displacement of the observed drifters was $139 \mathrm{~km}$ while the numerical drifters had an average net displacement of $97 \mathrm{~km}$ resulting in a net separation rate of $1.4 \mathrm{~km} \mathrm{day}^{-1}$ (Table 5). Most of the separation for the October 2000 drifters was in the along-shelf direction (Figure 9).

The winds were generally along-shelf to the southwest as was the movement of both observed and numerical drifters. The largest change in the separation distance (Figure $9 \mathrm{a}$ and $\mathrm{b}$ ) occured during a wind event on 9-10 October. The EDAS model winds were similar to the observed winds during this event, and the model captured the southward along-shelf velocity at the R6 Tower. In the middle of the month, when the winds were calm, there was almost no change in the separation distance between the numerical and observed drifters.

\subsection{January 2001 releases}

Similar to the April 2000 drifters, the observed January release drifters had a crossshelf component that was not captured by the numerical drifters (Figure 10). The observed drifters also had a larger along-shelf component of movement than the numerical drifters (Figure 10). The average net displacement of the observed drifters was $64 \mathrm{~km}$ and the separation distance growth rate from drifter release is $2.1 \mathrm{~km}^{-1 a y}$ (Table 5). 
The winds during the January 2001 drifter release period alternated in direction with the strongest winds along-shelf to the southwest. The change in drifter separation was highest (Figure 11) during high wind events: February 4-5, 12-13, and 19. The separation distance changed very little between wind events. During these same wind events, there was a cross-shelf flow evident in the observations at the R6 Tower that was not captured in the model results. In the along-shelf direction, the model velocity generally matched the observations in timing but not the magnitude of the peaks. The comparison of observed coastal water level with model results is generally better from the middle of the month.

\subsection{March 2001 releases}

For the drifters released in March 2001 the average displacement of the observed drifters was only $30 \mathrm{~km}$. Two of the drifters had net displacements of only $19 \mathrm{~km}$ and $22 \mathrm{~km}$ after one month. The average net displacement of the observed drifters was $37 \mathrm{~km}$ and the separation distance growth rate from drifter release is $2.0 \mathrm{~km} \mathrm{day}^{-1}$ (Table 5).

The winds were quite variable due to the passage of several large storms through the area (Figure 12b). The misfit in the cross-shelf winds was highest during this release period (Table 3). Again, during wind events, the model water velocities (Figure 12d) were of smaller magnitude than the observed. The observed crossshelf flow, evident at the R6 Tower, and possibly caused by the fresh-water intrusion seen at the R2 Tower (Figure 3), was not captured in the model.

At the R2 Tower, the water column was well-mixed at the beginning of the March 2001 release period (Figure 3). Both the Altamaha and Satilla Rivers in south Geor- 
gia had larger than average discharges at the end of March into April 2001 coinciding with the freshening of the surface waters at the R2 Tower (see Figures 2 and 3) which created a stratified water column by 10 April. The observed drifters were likely affected by this unmodelled stratified flow which resulted in a maximum change in separation distance (see Figure 12a) on 18 April during a large wind event.

\section{Discussion}

Model results showed good agreement with Lagrangian data, on monthly time scales, producing a drifter separation rate of $1.7 \mathrm{~km} \mathrm{~d}^{-1}$ (excluding June) (Table 5). In comparison, a separation distance of $20 \mathrm{~km}$ after 6 days, or approximately $3.33 \mathrm{~km} \mathrm{~d}^{-1}$ was found for a single model and observed drifter released in Onslow Bay off the coast of North Carolina (Werner et al., 1999). On the West Florida Shelf, a separation distance of $35 \mathrm{~km}$ between one modeled and observed drifter at the end of 20 days, or approximately $1.75 \mathrm{~km} \mathrm{~d}^{-1}$ was found (Yang et al., 1999). Finally, a comparison of observed and numerical drifters along a tidal front for 3 days on Georges Bank resulted in an average separation slope of $2.35 \mathrm{~km} \mathrm{~d}^{-1}$ (Aretxabaleta et al., 2005). In this section, we consider the tidal, baroclinic and other unresolved components of the flow along with winds and drifter slippage as possible sources of error.

On monthly time scales, model results showed good agreement with Eulerian data during the time periods studied. Previous studies have shown that the tidal prediction in the southeast U.S continental shelf, especially for the $M_{2}$ tide and other semi-diurnal tides, is improved by including the estuaries along the Georgia/South Carolina coast (Blanton et al., 2004; Lynch et al., 2004). We did not include the 
estuaries in our model domain and, therefore, a misfit on the inner- and mid-shelf in the tidal band solution is expected and estimated to be on the order of $0.02 \mathrm{~m} \mathrm{~s}^{-1}$ (Blanton et al., 2004). Weak Lagrangian tidal residual drifts/velocities with peak values of $0.005 \mathrm{~m} \mathrm{~s}^{-1}$ were found on the inner- to mid-shelf (Werner et al., 1993a). Higher tidal residuals of $0.02-0.03 \mathrm{~m} \mathrm{~s}^{-1}$ exist near the tidal inlets (Kapolnai et al., 1996). With most of the drifters staying in the mid-shelf region, the long-term drifter trajectory will be affected by the weak tidal residuals on the shelf and should not be greatly affected by the misfit in the tidal currents. A comparison of the distance travelled by the model and observed drifters during a five-day period with very little wind (October 16-21, 2000) showed a mean difference of approximately $0.5 \mathrm{~km}$ in residual tidal displacement.

Another factor contributing to the discrepancy between the observed and numerical drifter positions is the unmodeled baroclinic component of the flow field. In the winter, shelf waters on the southeast U.S. continental shelf or off the coast of Georgia are weakly stratified with temperature and salinity well-mixed in the upper half of the water column on the inner and mid-shelf (Blanton et al., 2003). However, with freshwater discharge peaking in March and April, the inner shelf becomes more strongly stratified. The climatology results indicate that the densitydriven flow is generally weaker than the wind-driven flow in the inner-shelf but may be of the same magnitude for the mid-shelf region. In a study of the fate of river discharge on this shelf during the spring of 1984, it was shown that it takes about two months for the fresher surface water to cross the entire shelf. Kourafalou et al. (1996b) found that the preferred mean pathway is in the northeastward direction with removal from the shelf near Charleston, South Carolina in the vicinity of the Charleston Bump.

In general, the model underestimates the magnitude of the cross-shelf flow on the 
shelf. Cross-shelf flows have generally been more difficult to study and less well understood than along-shelf flows. Cross-shelf flows are not geostrophic and are influenced by processes occuring from mesoscale phenomenon such as coastal fronts (Allen et al., 1988) to very small $(<10 \mathrm{~km})$ scale aspects of the wind field affecting the surface boundary layer (Brink et al., 1990). On the SEUSCS, the cross-shelf flows are also influenced by the motions of the Gulf Stream (Oey, 1986; Oey et al., 1987; Brink et al., 1990) which is not included in the 3-D circulation model. Efforts to include the Gulf Stream in the 3-D circulation model are currently underway (Aretxabaleta, 2005).

The correction due to the differences in EDAS and observed wind stress may also contribute to the discrepancy between the observed and numerical drifter tracks (Edwards et al., accepted). This correction was made using observations at one location in the model domain and does not take into account the possibility of a spatial variation between EDAS and actual winds. Also, while we have attempted to include actual drifter slippage in our numerical drifter tracks, this is only an estimate of the drifter slippage and does not include any slippage due to the wave field. Further, the relationship used is only an approximation to the actual slippage and may vary with wind and wave conditions (Geyer, 1989).

\section{Concluding Remarks}

The present circulation field has been idealized in that stratification effects and offshore currents (e.g., the Gulf Stream and its instabilities) have not been included. We expect these to have differing effects on the results presented herein. In the mid- to inner-shelf, frontal zones may increase retention, while near the shelf edge entrainment into neighboring currents may decrease retention. However, the agree- 
ment between observed and modeled results (of drifter trajectories) found in this study covering an entire year of sampling (inter-seasonal) on the SAB suggests that the time-scales we identified in this study are "reasonable" and their ecological significance needs further exploration. While our study focused on the Lagrangian processes on the southeast U.S. continental shelf, the modeling methods and conclusions may be applicable to similar continental shelves worldwide. By including specific characteristics of the observed drifters in the numerical drifter trajectories, we provide a more realistic understanding of their movement on the shelf.

Several future enhancements to the modeling effort are apparent. The use of a more refined shelf mesh would help to enhance small scale cross-shelf motions not captured in the present solution (Werner et al., 1999) and related dispersion (Ridderinkhof and Zimmerman, 1992). Similarly, and perhaps more significantly, the model does not include the baroclinic component of the flow field. With the development of a regional climatology (Blanton et al., 2003), the long-term monthly average effect could be included. However, with the recent increase in Ocean Observing Systems in the region (Seim et al., 2003), more data is becoming available to help provide the necessary initialization of the structure of the density field on the shelf. We are currently investigating the nesting of our regional model in the basinscale HYCOM circulation model (HYbrid Coordinate Ocean Model, Bleck (1998, 2002)). This would provide an initialization to the density field on the shelf, as well as boundary conditions containing far field effects and a reasonable approximation to the Gulf Stream. An additional enhancement is the use of data assimilation techniques (Aikman et al., 1996; Lynch et al., 2001). Using data assimilation in a model of Georges Bank, Aretxabaleta et al. (2005) show a reduction in a comparison of observed and numerical model separation rates for two different time periods from 4.05 and $2.69 \mathrm{~km} \mathrm{~d}^{-1}$ (before data assimilation) to 2.59 and $1.58 \mathrm{~km} \mathrm{~d}^{-1}$ (after data 
assimilation).

In the nearshore, the effect of the estuaries and sounds on the tidal flows in this region of the shelf has been shown by Blanton et al. (2004) and Lynch et al. (2004) . Specifically, to properly capture the semi-diurnal tidal flows and tidal elevations within $10-15 \mathrm{kms}$ of the shelf, the estuarine system must be explicitly included. We have not included these in the present model solutions. Of similar importance is the effect of the freshwater discharge onto the shelf particularly in the formation of the coastal front zone and associated circulation (Werner et al., 1993a; Kourafalou et al., 1996a). The details of the coastal front zone are likely to affect drifter trajectories trapped within or in its vicinity and account for some of the discrepancies between the observed and modelled drifter trajectories noted in our present study. Finally, improvements in forecast meteorological variables over the oceanic regions are underway and will help improve estimates of atmospheric forcing of oceanic motions (Xue et al., 2000). We anticipate that future studies will include explicit attempts to coupling of the atmosphere and ocean components more routinely.

The drifters describe the seasonal circulation and possible larval dispersal pathways on the shelf due to the changing wind regime (Weber and Blanton, 1980; Blanton et al., 1985). The observed drifters provide a picture of the average circulation in the top 10 to $15 \mathrm{~m}$ of the water column while the numerical drifters provide a look at the movement of water parcels at $10 \mathrm{~m}$ depth. The numerical drifters were a good approximation of the observed drifter movement. The combination of observed and numerical drifter tracks indicate that populations of marine organisms in the central mid-shelf region might be relatively closed on the scale of 1-2 months owing to the retention of larvae off the coast of Georgia. The effect of circulation and larval behavior on larval transport pathways in the region will be examined in more detail in future studies. 


\section{Acknowledgements}

Funding from SEACOOS and a contract from the Center for Coastal Fisheries and Habitat Research to the University of North Carolina - Chapel Hill from funds provided by the Office of National Marine Sanctuaries (NOAA NOS) in support of research at Gray's Reef National Marine Sanctuary is gratefully acknowledged.

\section{References}

Aikman, F., Mellor, G. L., Ezer, T., Sheinin, D., Chen, P., Breaker, L., Bosley, K., Rao, D. B., 1996. Towards an operational nowcast/forecast system for the U.S. east coast. In: Malanotte-Rizzoli, P. (Ed.), Modern Approaches to Data Assimilation in Ocean Modeling. Elsevier Science, pp. 347-376.

Aliani, S., Griffa, A., Molcard, A., 2003. Floating debris in the Ligurian sea, northwestern Mediterranean. Marine Pollution Bulletin 46, 1142-1149.

Allen, J., Bane, J., Brink, K., Brooks, D., Brown, W., Caldwell, D., Collins, C., Guza, R., Jumars, P., Royer, T., 1988. Coastal Physical Oceanography (CoPO): Towards a National Plan. Report of a Meeting of the Coastal Oceanography Physical Oceanography Community held January 23-2 in Gulf Park, Mississippi, sponsored by the National Science Foundation.

Aretxabaleta, A., 2005. Baroclinic processes in coastal oceans: observations and modeling on Georges Bank and the South Atlantic Bight continental shelf. Ph.D. thesis, University of North Carolina - Chapel Hill.

Aretxabaleta, A., Manning, J., Werner, F. E., Smith, K., Blanton, B. O., Lynch, D., 2005. Data Assimilative Hindcasting on the Southern Flank of Georges Bank during May 1999: frontal circulation and implications. Continental Shelf Research $25(7 / 8), 849-874$. 
Aretxabaleta, A., Nelson, J. R., Blanton, J. O., Seim, H. E., Werner, F. E., Bane, J. M., Weisberg, R., accepted. Cold Event in the South Atlantic Bight During Summer of 2003: Anomalous Hydrographic and Atmospheric Conditions. J. Geophys. Res.

Barans, C. A., Roumillat, W. A., 1978. Surface water drift south of Cape Lookout, North Carolina. In: J.R. Goulet, J., Haynes, E. (Eds.), Ocean variability: Effects on U.S. marine fishery resources. NOAA Tech. Rep. NMFS Circ. 416, Washingtin, D. C., pp. 299-308.

Bartsch, J., Brander, K., Heath, M., Munk, P., Richardson, K., Svendsen, E., 1989. Modelling the advection of herring larvae in the North Sea. Nature 340, 632-636. Blanton, B. O., 1993. User's Manual for 3-Dimensional drogue tracking on a finite element grid with linear finite elements. Tech. rep., UNC Marine Science, Chapel Hill, NC.

Blanton, B. O., 2003. Towards operational modeling in the South Atlantic Bight. Ph.D. thesis, University of North Carolina - Chapel Hill.

Blanton, B. O., Aretxabaelta, A., Werner, F. E., Seim, H. E., 2003. Monthly climatology of the continental shelf waters of the South Atlantic Bight. J. Geophys. Res. 108 (C8), 20-1,20-19.

Blanton, B. O., Werner, F. E., Seim, H., Luettich, Jr., R. A., Lynch, D. R., Smith, K. W., Voulgaris, G., Bingham, F. M., Way, F., 2004. Barotropic tides in the South Atlantic Bight. J. Geophys. Res. 109 (C12024), doi:10.1029/2004JC002455.

Blanton, J. O., Schwing, F. B., Weber, A. H., Pietrafesa, L. J., Hayes, D. W., 1985. Wind stress climatology in the South Atlantic Bight. In: Atkinson, L. P., Menzel, D. W., Bush, K. A. (Eds.), Oceanography of the Southeastern U. S. Continental Shelf. American Geophysical Union, Washingtin, D. C., pp. 10-22.

Bleck, R., 1998. Ocean modeling in isopycnic coordinates. In: Chassignet, E. P., Verron, J. (Eds.), Ocean Modeling and Parameterization. Kluwer Academic Pub- 
lishers, pp. 423-448.

Bleck, R., 2002. An oceanic general circulation model framed in hybrid isopycniccartesion coordinates. Journal of Geophysical Research 4, 55-88.

Boicourt, W. C., W. J. Wiseman, J., Valle-Levinson, A., Atkinson, L. P., 1998. Continental shelf of the southeastern United States and the Gulf of Mexico: in the shadow of the western boundary current. In: The Sea. Vol. 11. Academic Press, pp. 135-182.

Brink, K. H., Bane, J. M., Church, T. M., Fairall, C. W., Geernaert, G. L., Gorsline, D. S., Guza, R. T., Hammond, D. E., Knauer, G. A., Martens, C. S., Milliman, J. D., Nittrouer, C. A., Peterson, C. H., Rogers, D. P., Roman, M. R., Yoder, J. A., 1990. Coastal ocean processes (CoOP): Results of an Interdisciplinary Workshop.

Caley, M. J., Carr, M. H., Hixon, M. A., Hughes, T. P., Jones, G. P., Menge, B. A., 1996. Recruitment and the local dynamics of open marine populations. Annual Review of Ecological Systems 27, 477-500.

Capella, J. E., Quetin, L. B., Hofmann, E. E., Ross, R. M., 1992. Models of the early life history of euphausia superba -Part I: Lagrangian calculations. Deep Sea Research 69 (7/8), 1201 - 1220.

Churchill, J. H., Blanton, J. O., Hench, J. L., Luettich, Jr., R. A., Werner, F. E., 1999. Flood Tide Circulation Near Beaufort Inlet, North Carolina: Implications for Larval Recruitment. Estuaries 22 (4), 1057-1070.

Cowen, R. K., Gawarkiewicz, G., Pineda, J., Thorrold, S., Werner, F. E., 2002. Population Connectivity in Marine Systems. Report of a Workshop to Develop Science Recommendations for the National Science Foundation.

Cowen, R. K., Lwiza, K. M. M., Sponaugle, S., Paris, C. B., Olson, D. B., 2000. Connectivity of Marine Populations: Open or Closed? Science 287, 857-859.

Crowder, L. B., Lyman, S. J., Figueira, W. F., Priddy, J., 2000. Source-sink popu- 
lation dynamics and the problem of siting marine reserves. Bulletin of Marine Science 66 (3), 799-820.

Davis, R. E., 1985. Drifter observations of coastal surface currents during code: The statistical and dynamical views. J. Geophys. Res. 90 (9), 4756-4772.

Davis, R. E., 1991. Lagrangian ocean studies. Annual Review of Fluid Mechanics $23,43-64$.

Edwards, K. P., Werner, F. E., Blanton, B. O., accepted. Comparison of observed and modeled drifters trajectories in coastal regions: an improvement through adjustments for observed drifter slip and errors in wind fields. Journal of Atmospheric and Oceanic Technology.

Geyer, W. R., 1989. Field calibration of mixed layer drifters. Journal of Atmospheric and Oceanic Technology 6, 333-342.

Glenn, S. M., Ebbesmeyer, C. C., 1994. The structure and propagation of a Gulf Stream frontal eddy along the North Carolina shelf break. J. Geophys. Res. 99 (C3), 5029-5046.

Grantham, B. A., Eckert, G. L., Shanks, A. L., 2003. Dispersal potential of marine invertebrates in diverse habitats. Ecological Applications 13 (1), S108-S116.

Guénette, S., Lauck, T., Clark, C., 1998. Marine reserves: from Beverton and Holt to the present. Reviews in Fish Biology and Fisheries 8, 251-272.

Hare, J. A., Churchill, J. H., Cowen, R. K., Berger, T. J., Cornillon, P. C., Dragos, P., Glenn, S. M., Govoni, J. J., Lee, T. N., 2002. Routes and rates of larval fish transport from the southeast to the northeast United States continental shelf. Limnology and Oceanography 47 (6), 1774-1789.

Hare, J. A., Quinlan, J. A., Werner, F. E., Blanton, B. O., Govoni, J. J., Forward, R. B., Settle, L. R., Hoss, D. E., 1999. Larval transport during winter in the SABRE study area: results of a coupled vertical larval behaviour-threedimensional circulation model. Fisheries Oceanography 8 (S2), 57-76. 
Haynes, R., Barton, E. D., 1991. Lagrangian observations in the Iberian coastal transition zone. J. Geophys. Res. 96 (15), 14731-14741.

Hermann, A. J., Hinckley, S., Megrey, B. A., Stabeno, P. J., 1996. Interannual variability of the early life history of walleye pollock near Shelikof Strait as inferred from a spatially explicit, individual-based model. Fisheries Oceanography 5 (S1), 39-70.

Kapolnai, A., Werner, F. E., Blanton, J. O., 1996. Circulation, mixing, and exchange processes in the vicinity of tidal inlets: a numerical study. Journal of Geophysical Research 101 (C6), 14253-14268.

Kinlan, B. P., Gaines, S. D., 2003. Propagule dispersal in marine and terrestrial environments: a community perspective. Ecology 84 (8), 2007-2020.

Kourafalou, V. H., Lee, T. N., Oey, L. Y., Wang, J. D., 1996a. The fate of river discharge on the continental shelf 2 . Transport of coastal low-salinity waters under realistic wind and tidal forcing. J. Geophys. Res. 101 (C2), 3435-3455.

Kourafalou, V. H., Oey, L. Y., Wang, J. D., Lee, T. N., 1996b. The fate of river discharge on the continental shelf 1 . Modeling the river plume and the inner shelf coastal current. J. Geophys. Res. 101 (C2), 3415-3434.

Large, W. G., Pond, S., 1981. Open ocean momentum flux measurements in moderate to strong winds. J. of Phys. Oceanogr. 11 (3), 324-336.

Larson, M. R., Foreman, M. G. G., Levings, C. D., Tarbotton, M. R., 2003. Dispersion of discharged ship ballast water in Vancouver Harbor, Juan De Fuca Strait, and offshore of the Washington Coast. J. Environ. Eng. Sci. 2, 163-176.

Lee, T. N., Atkinson, L. P., 1983. Low-frequency current and temperature variability from Gulf Stream frontal eddies and atmospheric forcing along the southeast U.S. outer continental shelf. J. Geophys. Res. 88 (C8), 4541-4567.

Lee, T. N., Atkinson, L. P., Legekis, R., 1981. Observations of a Gulf Stream frontal eddy on the Georgia continental shelf, April 1977. Deep Sea Research 28 (4), 
$347-378$.

Lee, T. N., Yoder, J. A., Atkinson, L. P., 1991. Gulf Stream frontal eddy influence on productivity of the southeast U.S. continental shelf. J. Geophys. Res. 96 (C12), 22191-22205.

Limeburner, R., Beardsley, R. C., 1996. Near-surface circulation over Georges Bank. Deep-Sea Research II 43, 1547-1574.

Lockwood, D. R., Hastings, A., Botsford, L. W., 2002. The Effects of Dispersal Patterns on Marine Reserves: Does the Tail Wag the Dog. Theoretical Population Biology 61, 297-301.

Lozier, M. S., Gawarkiewicz, G., 2001. Cross-frontal exchange in the Middle Atlantic Bight as evidenced by surface drifters. JPO 31, 2498-2510.

Lugo-Fernández, A., Deslarzes, K. J. P., Price, J. M., Boland, G. S., Morin, M. V., 2001. Inferring probable dispersal of Flower Garden Banks Coral Larvae (Gulf of Mexico) using observed and simulated drifter trajectories. Continental Shelf Research 21, 47-67.

Lynch, D. R., Ip, J. T. C., Naimie, C. E., Werner, F. E., 1996. Comprehensive coastal circulation model with application to the Gulf of Maine. Cont. Shelf Res. 16, 875-906.

Lynch, D. R., Naimie, C. E., Ip, J. T., Lewis, C. V., Werner, F. E., Luettich, R. A., Blanton, B. O., Quinlan, J. A., McGillicuddy, D. J., Ledwell, J. R., Churchill, J., Kosnyrev, V., Davis, C. S., Gallager, S. M., Ashjian, C. J., Lough, R. G., Manning, J., Flagg, C. N., Hannah, C. G., Gorman, R. C., 2001. Real-time data assimilative modeling on Georges Bank. Oceanography 14 (1), 65-77.

Lynch, D. R., Smith, K., Blanton, B. O., Werner, F. E., Luettich, R., 2004. Forecasting the coastal ocean: Resolution, Tide and Operational data in the South Atlantic Bight. J. Atmos. Oceanic Technology (7), 1074-1085.

Lynch, D. R., Werner, F. E., 1991. Three-dimensional hydrodynamics on finite el- 
ements. Part II: Non-linear time-stepping model. Int. J. Numer. Methods Fluids 12, 507-533.

Manning, J. P., Lough, R. G., Naimie, C. E., Churchill, J. H., 2001. Modelling the effect of a slope-water intrusion on advection of fish larvae in May 1995 on Georges Bank. ICES Journal of Marine Science 58, 985-993.

Mariano, A. J., Griffa, A., Özgökmen, T. M., Zambianchi, E., 2002. Lagrangian Analysis and Predictability of Coastal and Ocean Dynamics 2000. Journal of Atmospheric and Oceanic Technology 19, 1114-1126.

Mora, C., Sale, P. F., 2002. Are populations of coral reef fish open or closed? TRENDS in Ecology and Evolution 17 (9), 422-428.

Naimie, C. E., Limeburner, R., Hannah, C. G., Beardsley, R. C., 2001. On the geographic and seasonal patterns of near-surface circulation on Georges Bank - from real and simulated drifters. Deep-Sea Research II 48, 501-518.

Oey, L. Y., 1986. The formation and maintenance of density fronts on the u.s. southeastern continental shelf during winter. J. of Phys. Oceanogr. 16, 1121-1135.

Oey, L. Y., Atkinson, L. P., Blanton, J. O., 1987. Shoreward intrusion of upper gulf stream water onto the u.s. southeastern continental shelf. J. of Phys. Oceanogr. 17, 2318-2333.

Paduan, J. D., Niiler, P. P., 1990. A Lagrangian description of motion in northern California coastal transition filaments. J. Geophys. Res. 95 (14), 18095-18109.

Palumbi, S. R., 2003. Population genetics, demographic connectivity, and the design of marine reserves. Ecological Applications 13 (1), S146-S158.

Pape, E. H., Garvine, R. W., 1982. The subtidal circulation in Delaware Bay and adjacent shelf waters. J. Geophys. Res. 87, 7955-7970.

Parada, C., Lingen, C. D. V. D., Mullen, C., Penven, P., 2003. Modelling the effect of buoyancy on the transport of anchovy (engraulis capensis) eggs from spawning to nursery grounds in the southern Benguala: an IBM approach. Fisheries 
Oceanography $12(3), 170-184$.

Pedersen, O. P., Aschan, M., Rasmussen, T., Tande, K. S., Slagstad, D., 2003. Larval dispersal and mother populations of pandalus borealis investigated by a Lagrangian particle-tracking model. Fisheries Research 65, 173-190.

Poulain, P. M., 1999. Drifter observations of surface circulation in the adriatic sea between december 1994 and march 1996. Journal of Marine Systems 20, 231253.

Poulain, P. M., 2001. Adriatic Sea circulation as derived from drifter data between 1990 and 1999. Journal of Marine Systems 29, 3-32.

Poulain, P. M., Warn-Varnas, A., Niiler, P. P., 1996. Near-surface circulation of the nordic seas as measured by lagrangian drifters. J. Geophys. Res. 101, 1823718258.

Quinlan, J. A., Blanton, B. O., Miller, T. J., Werner, F. E., 1999. From spawning grounds to the estuary: using linked individual-based and hydrodynamic models to interpret patterns and processes in the oceanic phase of Atlantic menhaden brevoortia tyrannus life history. Fisheries Oceanography 8 (S2), 224-246.

Reid, J. L., Schwartzlose, R. A., Brown, D. M., 1963. Direct measurements of a small surface eddy off northern Baja California. J. Mar. Res. 21, 205-18.

Ridderinkhof, H., Zimmerman, J. T. F., 1992. Chaotic Stirring in a Tidal System. Science 248, 1107-1111.

Roberts, C. M., 1997. Connectivity and Management of Caribbean Coral Reefs. Science 278, 1454-1457.

Seim, H., 2000. Implementation of the South Atlantic Bight Synoptic Offshore Observational Network. Oceanography 13, 18-23.

Seim, H., Bacon, R., Barans, C., Fletcher, M., Gates, K., Jahnke, R., Kearns, E., Lea, R., Luther, M., Mooers, C., Nelson, J., Porter, D., Shay, L., Spranger, M., Thigpen, J., Weisberg, R., Werner, F., 2003. Sea-coos - a model for a multi- 
state, multi-institutional regional observation system. Marine Technology Society Journal 37 (3), 92-101.

Shanks, A. L., Grantham, B. A., Carr, M. H., 2003. Propagule dispersal distance and the size and spacing of marine reserves. Ecological Applications 13 (1), S159-S169.

Spaulding, M. L., Kolluru, V. S., Anderson, E., Howlett, E., 1994. Application of Three-Dimensional Oil Spill Model (WOSM/OILMAP) to Hindcast the braer spill. Spill Science \& Technology Bulletin 1 (1), 23-35.

Stefánsson, U., Atkinson, L. P., Bumpus, D. F., 1971. Hydrographic properties and circulation of the North Carolina shelf and slope waters. Deep-Sea Research 18, $383-420$.

Stegmann, P. M., Quinlan, J. A., Werner, F. E., Blanton, B. O., Berrien, P., 1999. Atlantic menhaden recruitment to a southern estuary: defining potential spawning regions. Fisheries Oceanography 8 (S2), 111-123.

Tseng, R. S., Shen, Y. T., 2003. Lagrangian observations of surface flow patterns in the vicinity of Taiwan. Deep Sea Research 50, 1107-1115.

van Aken, H. M., 2002. Surface currents in the Bay of Biscay as observed with drifters between 1995 and 1999. Deep Sea Research 49, 1071-1086.

Weber, A. H., Blanton, J. O., 1980. Monthly mean wind fields for the South Atlantic Bight. J. Phys. Ocean. 10, 1256-1263.

Werner, F. E., Blanton, B. O., Quinlan, J. A., R. A. Luettich, J., 1999. Physical oceanography of the North Carolina continental shelf during the fall and winter seasons: implications for the transport of larval menhaden. Fisheries Oceanography 8 (Suppl. 2), 7-21.

Werner, F. E., Blanton, J. O., Lynch, D. R., Savidge, D. K., 1993a. A numerical study of the continental shelf circulation of the U.S. South Atlantic Bight during the autumn of 1987. Cont. Shelf Res. 13 (8/9), 871-997. 
Werner, F. E., Mackenzie, B. R., Perry, R. I., Lough, R. G., Naimie, C. E., Blanton, B. O., Quinlan, J. A., 2001. Larval trophodynamics, turbulence and drift on Georges Bank: A sensitivity analysis of cod and haddock. Scientia Marina 65 (Suppl 1), 99-115.

Werner, F. E., Page, F. H., Lynch, D. R., Loder, J. W., Lough, R. G., Perry, R. I., Greenberg, D. A., Sinclair, M. M., 1993b. Influences of mean advection and simple behavior on the distribution of cod and haddock early life stages on Georges Bank. Fisheries Oceanography 2 (43-64), 1793-1822.

Werner, F. E., Perry, R. I., Lough, R. G., Naimie, C. E., 1996. Trophodynamic and advective influences on Georges Bank larval cod and haddock. Deep-Sea Research II 43 (7-8), 1793-1822.

Xue, H., Pan, Z., Bane, Jr., J. M., 2000. A 2D coupled atmosphere-ocean model study of air-sea interactions during a cold air advection over the Gulf Stream. Mon. Wea. Rev. 128, 973-966.

Yang, H., Weisberg, R. H., Niiler, P. P., Sturges, W., Johnson, W., 1999. Lagrangian circulation and forbidden zone on the West Florida Shelf. Cont. Shelf Res. 19, $1221-1245$.

Yeung, C., Lee, T. N., 2002. Larval transport and retention of the spiny lobster,panularis argus, in the coastal zone of the Florida Keys, USA. Fisheries Oceanography 11 (5), 286-309. 


\section{List of Figures}

1 The Southeast U.S. continental shelf [North Carolina (NC), South Carolina (SC), Georgia (GA) and Florida (FL)] and the model domain used in this study. The location of the SABSOON R6 and R2 Towers are shown with triangles. Gray's Reef National Marine Sanctuary is shown with a square and the Ft. Pulaski and St. Augustine NOS water level stations are shown with diamonds. The 15-, 25-, 50-, 75-, 100-, 500- and 1000-m isobaths are shown. The axes are latitude in ${ }^{\circ} \mathrm{N}$ and longitude in ${ }^{\circ} \mathrm{W}$.

2 Daily for 2000/2001(thick line) and long-term monthly average (thin line) river discharge for the 6 largest rivers on the SAB (from north to south). The shaded periods indicate when the drifters were tracked. Note that the scale on the $y$-axis varies for each river (from the USGS website: http://nwis.waterdata.usgs.gov/usa/nwis/discharge).

3 Difference between the near-surface and near-bottom density from the SABSOON R2 Tower for each of the drifter release periods in 2000 and 2001.

4 A close-up view of the Georgia coast and Grays Reef National Marine Sanctuary. Raw tracks of the 15 drifters released during 2000 and 2001 are shown.The axes are latitude in ${ }^{\circ} \mathrm{N}$ and longitude in ${ }^{\circ} \mathrm{W}$. 
5 Distance between modeled and observed drifters from release.

Linear regressions are shown for all data and all data excluding June 2000.

6 Comparison of one of the model (grey) and observed (black) drifter tracks for each of the 2000 release periods. The axes are latitude in ${ }^{\circ} \mathrm{N}$ and longitude in ${ }^{\circ} \mathrm{W}$.

7 a) Change in separation distance per day $\left(\mathrm{km} \mathrm{d}^{-1}\right)$ b) Comparison of observed and EDAS model along-(offset 0.15 Pascals) and cross-shelf wind stress. c) Comparison of model and observed demeaned water levels at Ft. Pulaski and St. Augustine (offset $0.5 \mathrm{~m}$ ) d) Comparison of model and observed along- (offset $0.25 \mathrm{~m} \mathrm{~s}^{-1}$ ) and cross-shelf velocities at R6.

9 Same as Figure 7 but for the October 2000 release period.

10 Same as Figure 6 but for the January and March 2001 release periods. The axes are latitude in ${ }^{\circ} \mathrm{N}$ and longitude in ${ }^{\circ} \mathrm{W}$.

11 Same as Figure 7 but for the January 2001 release period. 


\section{List of Tables}

1 Statistics of monthly weather-band misfit between low-pass filtered observed and modeled water level. The reported statistics are the mean $(\mathrm{m})$ and standard deviation $(\mathrm{m})$ of the observed water levels, rms size of the misfit between the observed and modeled water levels (m) and the correlation coefficient (C.C.) at Ft. Pulaski, Georgia and St. Augustine, Florida.

2 Statistics of monthly low-pass filtered along-shelf and cross-shelf currents at $10 \mathrm{~m}$ depth at the R6 Tower. The reported statistics are the mean $\left(\mathrm{m} \mathrm{s}^{-1}\right)$ and standard deviation $\left(\mathrm{m} \mathrm{s}^{-1}\right)$ of the observed currents at the R6 Tower and rms size of the demeaned misfit $\left(\mathrm{m} \mathrm{s}^{-1}\right)$ and the correlation coefficient (C.C.).

3 Statistics of the along-shelf and cross-shelf wind stress at GRNMS including: mean and standard deviation (Pascals) of the GRNMS observed winds and the wind stress misfit (Pascals) between low-pass filtered observed and EDAS analysis for the drifter periods and the correlation coefficient.

4 Drifter releases: first reported drifter time and location for the 15 drifters released near Gray's Reef National Marine Sanctuary in 2000 and 2001. The number of days which the observed drifters were tracked on the shelf, the along-trajectory distance $(\mathrm{km})$ and the net displacement $(\mathrm{km})$. 
5 Comparison of the drifter results. Reported are: the average number of days the observed and numerical drifters were tracked, the average distance $(\mathrm{km})$ between the start and end of the observed drifter track; the average ending separation distance $(\mathrm{km})$ between the observed and numerical drifters; a linear regression analysis of the average separation rate $\left(\mathrm{km} \mathrm{d}^{-1}\right)$ and its $\mathrm{r}^{2}$ value. 


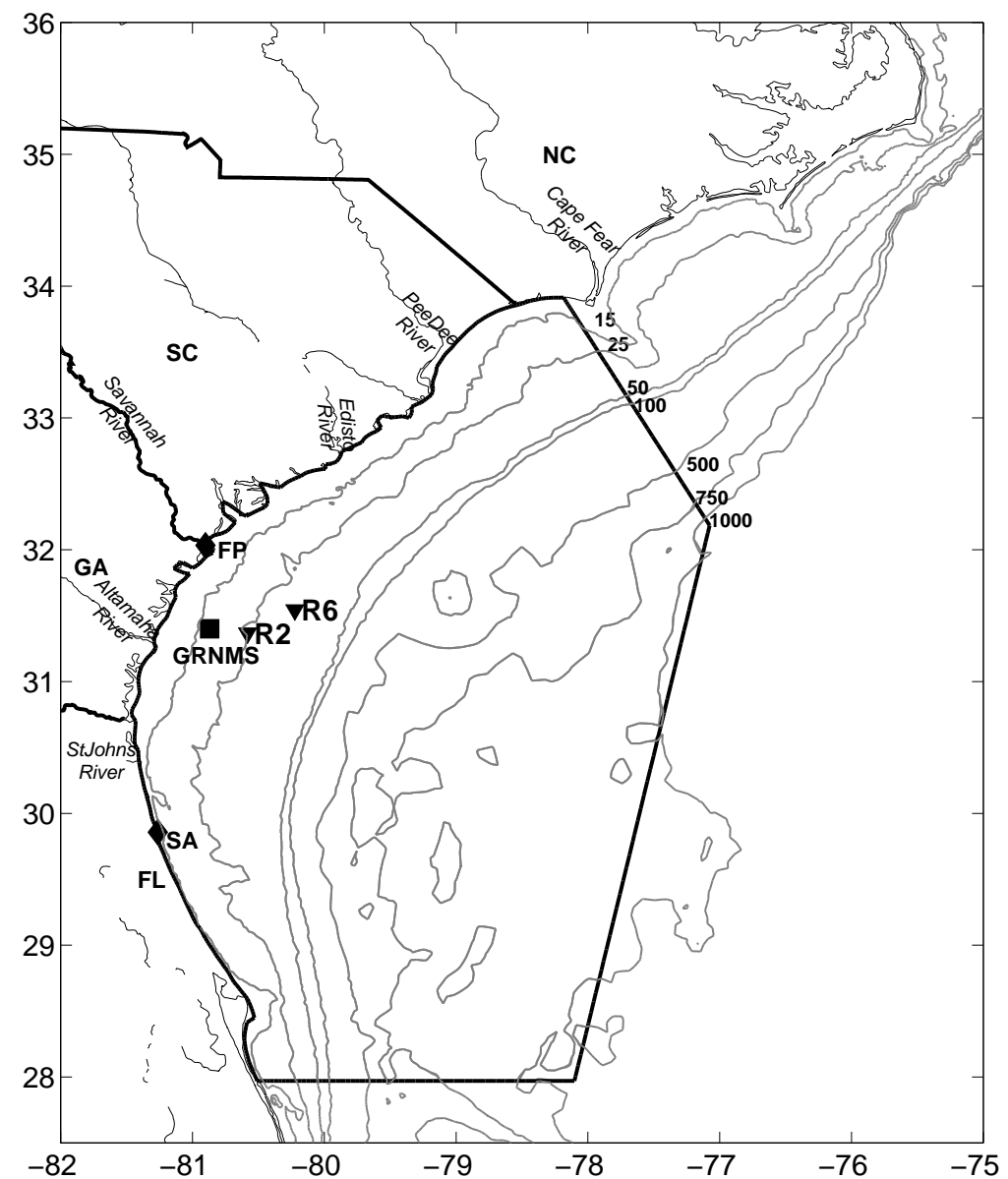

Fig. 1. The Southeast U.S. continental shelf [North Carolina (NC), South Carolina (SC), Georgia (GA) and Florida (FL)] and the model domain used in this study. The location of the SABSOON R6 and R2 Towers are shown with triangles. Gray's Reef National Marine Sanctuary is shown with a square and the Ft. Pulaski and St. Augustine NOS water level stations are shown with diamonds. The 15-, 25-, 50-, 75-, 100-, 500- and 1000-m isobaths are shown. The axes are latitude in ${ }^{\circ} \mathrm{N}$ and longitude in ${ }^{\circ} \mathrm{W}$. 

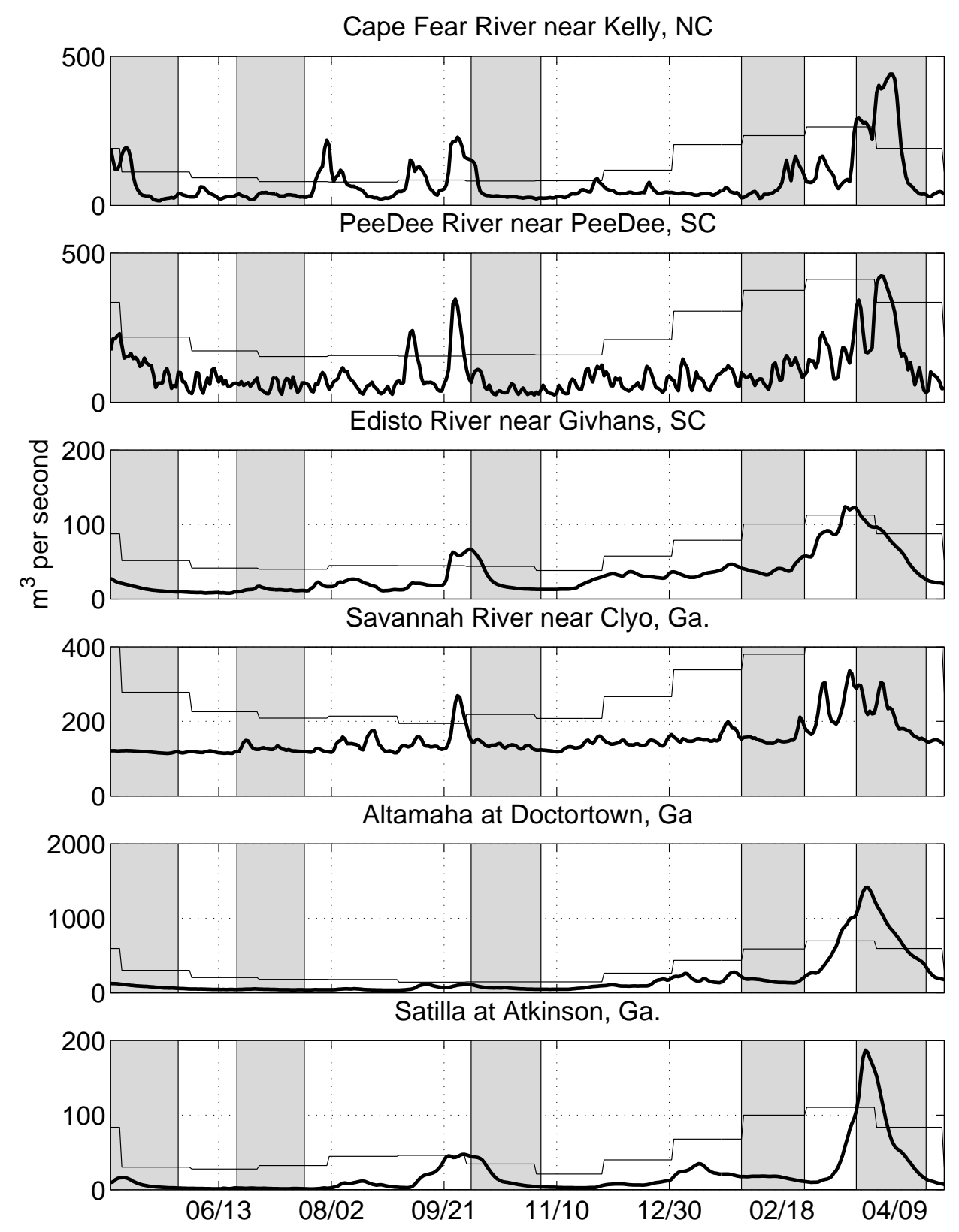

Fig. 2. Daily for 2000/2001(thick line) and long-term monthly average (thin line) river discharge for the 6 largest rivers on the SAB (from north to south). The shaded periods indicate when the drifters were tracked. Note that the scale on the y-axis varies for each river (from the USGS website: http://nwis.waterdata.usgs.gov/usa/nwis/discharge). 
Density Difference at $\mathrm{R} 2$
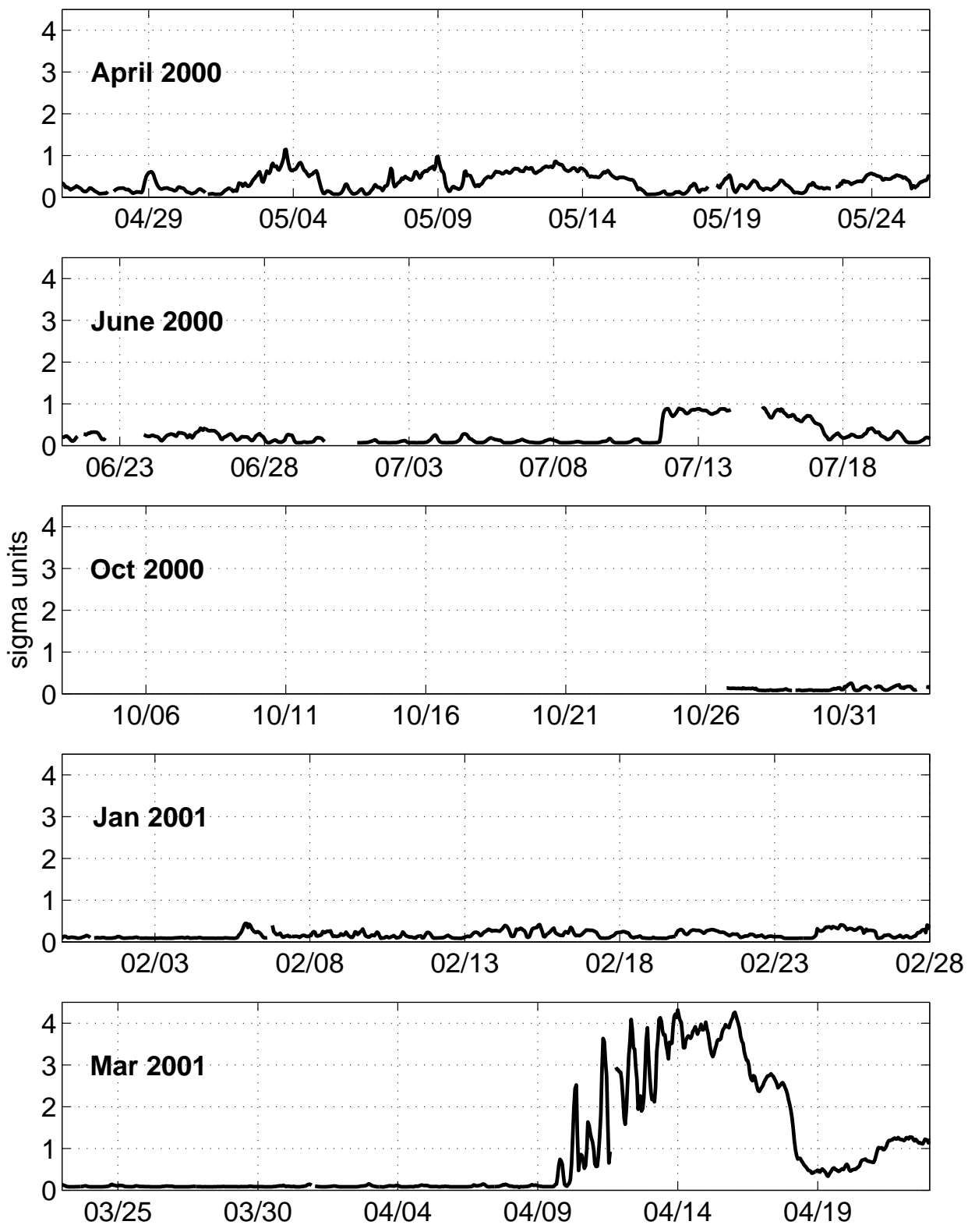

Fig. 3. Difference between the near-surface and near-bottom density from the SABSOON R2 Tower for each of the drifter release periods in 2000 and 2001. 


\begin{tabular}{|c|c|c|c|c|c|c|c|c|}
\hline & \multicolumn{4}{|c|}{ Ft. Pulaski } & \multicolumn{4}{|c|}{ St. Augustine } \\
\hline & \multicolumn{2}{|c|}{ Obs } & \multicolumn{2}{|c|}{ Misfit } & \multicolumn{2}{|c|}{ Obs } & \multicolumn{2}{|c|}{ Misfit } \\
\hline Release & Mean & Std Dev. & $\mathrm{rms}$ & C.C. & Mean & Std Dev & $\mathrm{rms}$ & C.C. \\
\hline Apr 2000 & -0.009 & 0.109 & 0.081 & 0.712 & -0.044 & 0.096 & 0.067 & 0.752 \\
\hline Jun 2000 & 0.023 & 0.129 & 0.082 & 0.815 & 0.016 & 0.120 & 0.077 & 0.782 \\
\hline Oct 2000 & 0.207 & 0.060 & 0.041 & 0.730 & 0.225 & 0.058 & 0.052 & 0.567 \\
\hline Jan 2001 & -0.079 & 0.116 & 0.070 & 0.848 & -0.104 & 0.101 & 0.065 & 0.798 \\
\hline Mar 2001 & -0.017 & 0.100 & 0.069 & 0.738 & -0.037 & 0.080 & 0.055 & 0.747 \\
\hline
\end{tabular}

Table 1

Statistics of monthly weather-band misfit between low-pass filtered observed and modeled water level. The reported statistics are the mean (m) and standard deviation (m) of the observed water levels, rms size of the misfit between the observed and modeled water levels (m) and the correlation coefficient (C.C.) at Ft. Pulaski, Georgia and St. Augustine, Florida. 


\begin{tabular}{|c|c|c|c|c|c|c|c|c|}
\hline & \multicolumn{3}{|c|}{ Along-Shelf } & \multicolumn{4}{c|}{ Cross-shelf } \\
\hline & \multicolumn{2}{|c|}{ Obs } & \multicolumn{2}{c|}{ Misfit } & \multicolumn{2}{c|}{ Obs } & \multicolumn{2}{c|}{ Misfit } \\
\hline Release & Mean & Std Dev. & rms & C.C & Mean & Std Dev. & rms & C.C \\
\hline \hline Apr 2000 & 0.034 & 0.094 & 0.069 & 0.710 & 0.006 & 0.054 & 0.052 & 0.550 \\
Jun 2000 & 0.114 & 0.148 & 0.139 & 0.560 & 0.027 & 0.041 & 0.045 & 0.292 \\
Oct 2000 & -0.038 & 0.041 & 0.053 & 0.794 & -0.015 & 0.065 & 0.042 & 0.209 \\
Jan 2001 & 0.004 & 0.121 & 0.070 & 0.897 & -0.019 & 0.065 & 0.066 & 0.270 \\
Mar 2001 & 0.014 & 0.093 & 0.062 & 0.789 & -0.025 & 0.050 & 0.055 & 0.245 \\
\hline
\end{tabular}

Table 2

Statistics of monthly low-pass filtered along-shelf and cross-shelf currents at $10 \mathrm{~m}$ depth at the R6 Tower. The reported statistics are the mean $\left(\mathrm{m} \mathrm{s}^{-1}\right)$ and standard deviation $\left(\mathrm{m} \mathrm{s}^{-1}\right)$ of the observed currents at the R6 Tower and rms size of the demeaned misfit $\left(\mathrm{m} \mathrm{s}^{-1}\right)$ and the correlation coefficient (C.C.). 


\begin{tabular}{|c|c|c|c|c|c|c|c|c|}
\hline & \multicolumn{4}{|c|}{ Along-Shelf } & \multicolumn{4}{|c|}{ Cross-shelf } \\
\hline & \multicolumn{2}{|c|}{ Obs } & \multicolumn{2}{|c|}{ Misfit } & \multicolumn{2}{|c|}{ Obs } & \multicolumn{2}{|c|}{ Misfit } \\
\hline Release & Mean & Std Dev. & $\mathrm{rms}$ & C.C & Mean & Std Dev. & $\mathrm{rms}$ & C.C \\
\hline Apr 2000 & 0.025 & 0.059 & 0.031 & 0.889 & -0.011 & 0.037 & 0.021 & 0.832 \\
\hline Jun 2000 & 0.035 & 0.056 & 0.031 & 0.871 & -0.011 & 0.040 & 0.027 & 0.767 \\
\hline Oct 2000 & -0.052 & 0.073 & 0.032 & 0.913 & 0.017 & 0.040 & 0.020 & 0.868 \\
\hline Mar 2001 & 0.003 & 0.060 & 0.029 & 0.915 & 0.009 & 0.064 & 0.032 & 0.890 \\
\hline
\end{tabular}

Table 3

Statistics of the along-shelf and cross-shelf wind stress at GRNMS including: mean and standard deviation (Pascals) of the GRNMS observed winds and the wind stress misfit (Pascals) between low-pass filtered observed and EDAS analysis for the drifter periods and the correlation coefficient. 


\begin{tabular}{|c|c|c|c|c|c|c|}
\hline & Release & & & Days & Along-Traj. & Net \\
\hline Drifter & Time & Latitude & Longitude & Tracked & Distance & Displacement \\
\hline 26819 & Apr 26, 2000 06:04 & -80.875 & 31.391 & 58.18 & 1,140 & 72 \\
\hline 26845 & Apr 26, 2000 06:24 & -80.885 & 31.377 & 58.17 & 1,222 & 76 \\
\hline 26856 & Apr 26, 2000 06:14 & -80.865 & 31.377 & 58.18 & 1,228 & 74 \\
\hline 26818 & Jun 21, 2000 11:16 & -80.871 & 31.390 & 58.56 & 2,118 & 1,334 \\
\hline 26844 & Jun 21, $200011: 26$ & -80.883 & 31.384 & 12.10 & 250 & 74 \\
\hline 26723 & Jun 21, 2000 11:31 & -80.885 & 31.373 & 22.15 & 463 & 166 \\
\hline 30351 & Oct 3, 2000 21:07 & -80.859 & 31.372 & 59.62 & 758 & 104 \\
\hline 30372 & Oct 3, 2000 20:58 & -80.871 & 31.388 & 59.69 & 878 & 66 \\
\hline 30374 & Oct 3, 2000 20:48 & -80.884 & 31.373 & 23.12 & 350 & 126 \\
\hline 16898 & $\operatorname{Jan} 30,200123: 52$ & -80.884 & 31.373 & 59.97 & 1,114 & 75 \\
\hline 16900 & Jan 30, $200123: 39$ & -80.872 & 31.388 & 51.73 & 1,058 & 114 \\
\hline 30416 & Jan 31, 2001 00:04 & -80.859 & 31.373 & 59.97 & 2,152 & 1,190 \\
\hline 30428 & Mar 22, 2001 16:18 & -80.865 & 31.377 & 38.12 & 851 & 156 \\
\hline 30442 & Mar 22, 2001 16:27 & -80.885 & 31.376 & 46.13 & 928 & 57 \\
\hline 30473 & Mar 22, 2001 16:11 & -80.883 & 31.391 & 55.15 & 1,129 & 40 \\
\hline
\end{tabular}

Table 4

Drifter releases: first reported drifter time and location for the 15 drifters released near Gray's Reef National Marine Sanctuary in 2000 and 2001. The number of days which the observed drifters were tracked on the shelf,4the along-trajectory distance $(\mathrm{km})$ and the net displacement $(\mathrm{km})$. 


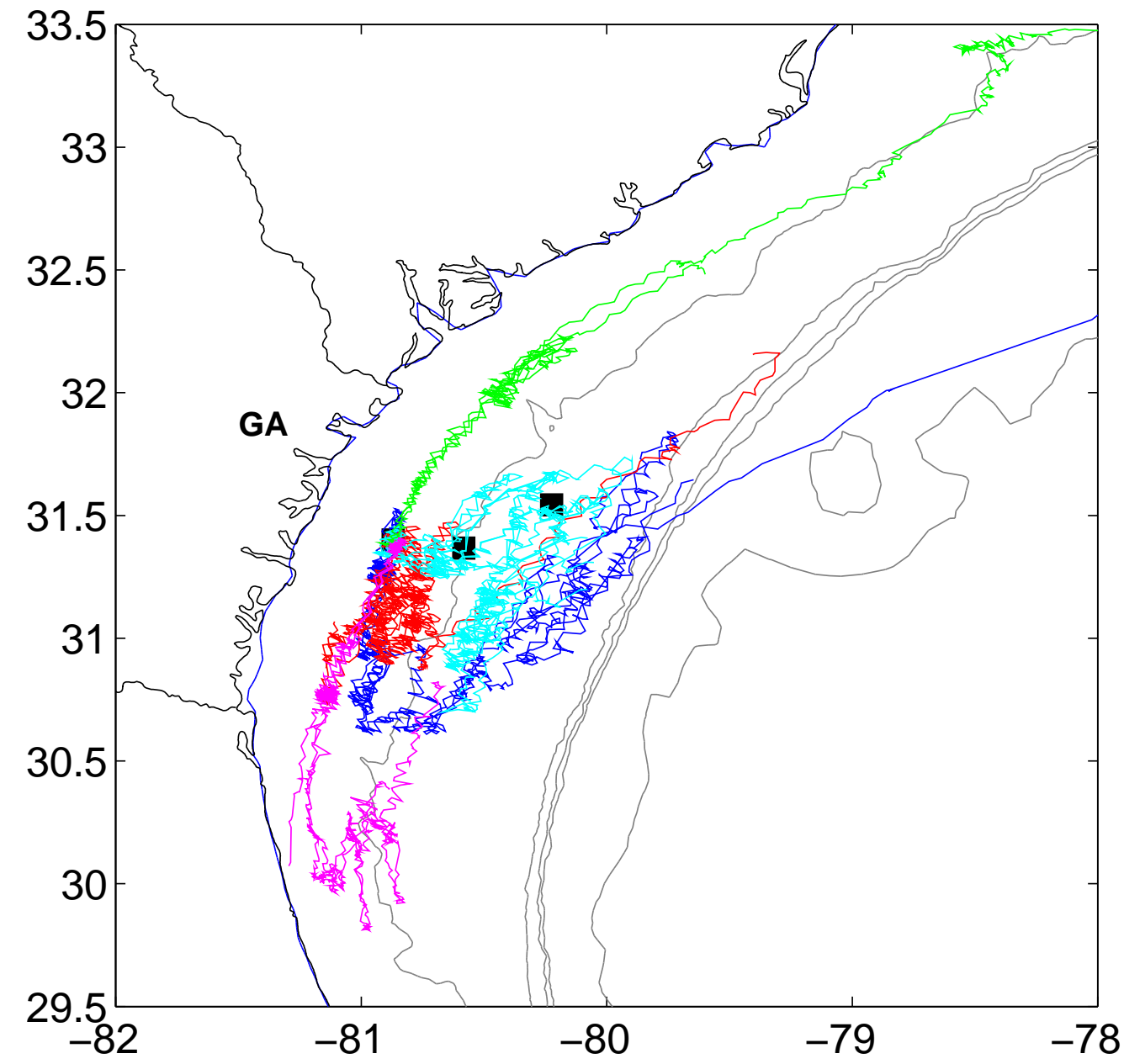

Fig. 4. A close-up view of the Georgia coast and Grays Reef National Marine Sanctuary. Raw tracks of the 15 drifters released during 2000 and 2001 are shown. The axes are latitude in ${ }^{\circ} \mathrm{N}$ and longitude in ${ }^{\circ} \mathrm{W}$. 


\begin{tabular}{|c|c|c|c|c|c|}
\hline Release & Avg. Days Tracked & Net Displacement & Obs-Mod & Avg. Sep. Rate & $\mathrm{r}^{2}$ \\
\hline \hline 26 Apr 2000 & 30 & 80 & 50 & 1.2 & 0.76 \\
21 Jun 2000 & 21 & 177 & 109 & 4.8 & 0.82 \\
3 Oct 2000 & 28 & 144 & 45 & 1.4 & 0.89 \\
30 Jan 2001 & 28 & 64 & 45 & 2.1 & 0.80 \\
22 Mar 2001 & 31 & 30 & 44 & 2.0 & 0.80 \\
\hline All & & & & 2.0 & 0.48 \\
Excl June & & & & 1.7 & 0.89 \\
\hline
\end{tabular}

Table 5

Comparison of the drifter results. Reported are: the average number of days the observed and numerical drifters were tracked, the average distance $(\mathrm{km})$ between the start and end of the observed drifter track; the average ending separation distance $(\mathrm{km})$ between the observed and numerical drifters; a linear regression analysis of the average separation rate $\left(\mathrm{km} \mathrm{d}^{-1}\right)$ and its $\mathrm{r}^{2}$ value. 


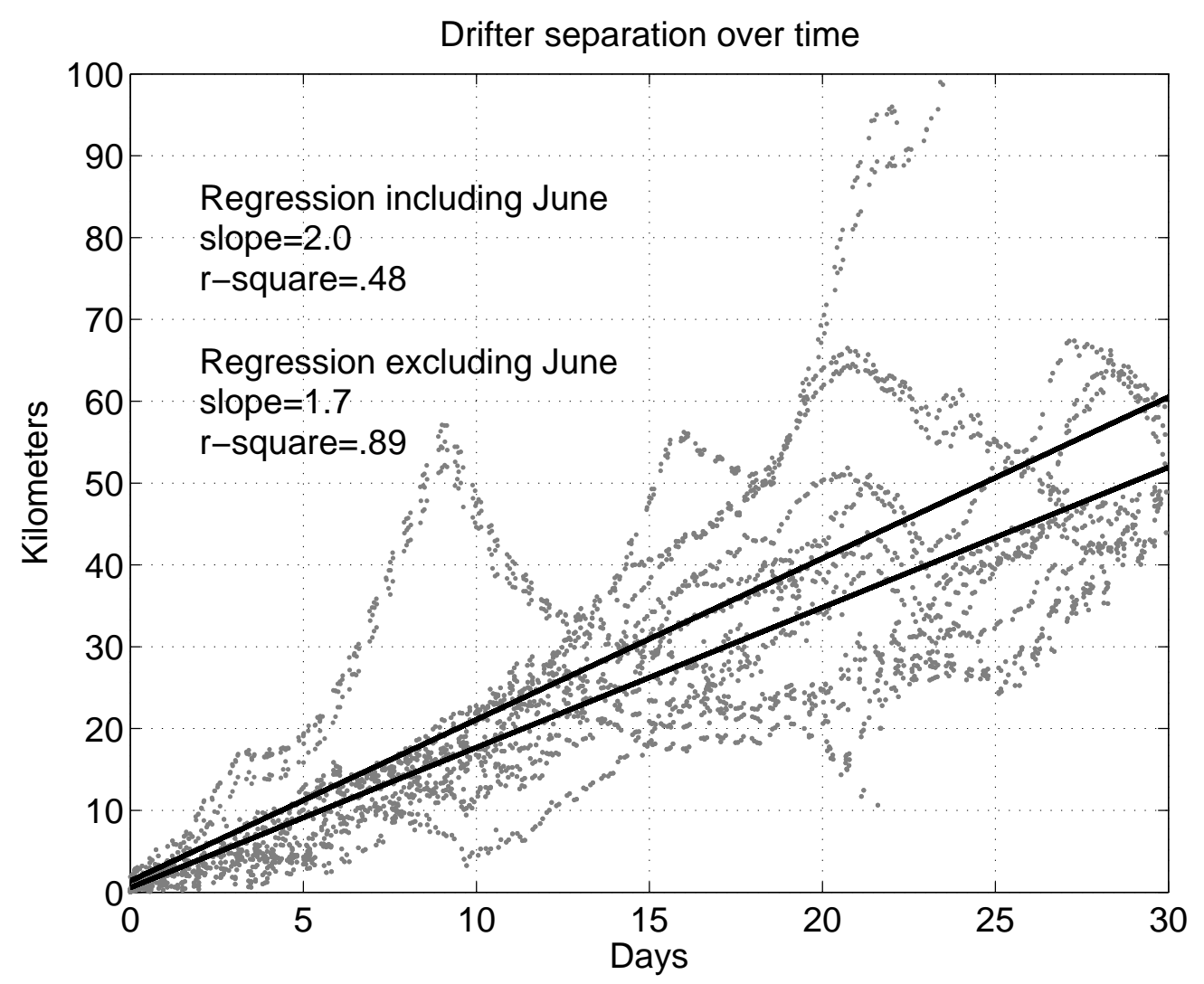

Fig. 5. Distance between modeled and observed drifters from release. Linear regressions are shown for all data and all data excluding June 2000. 


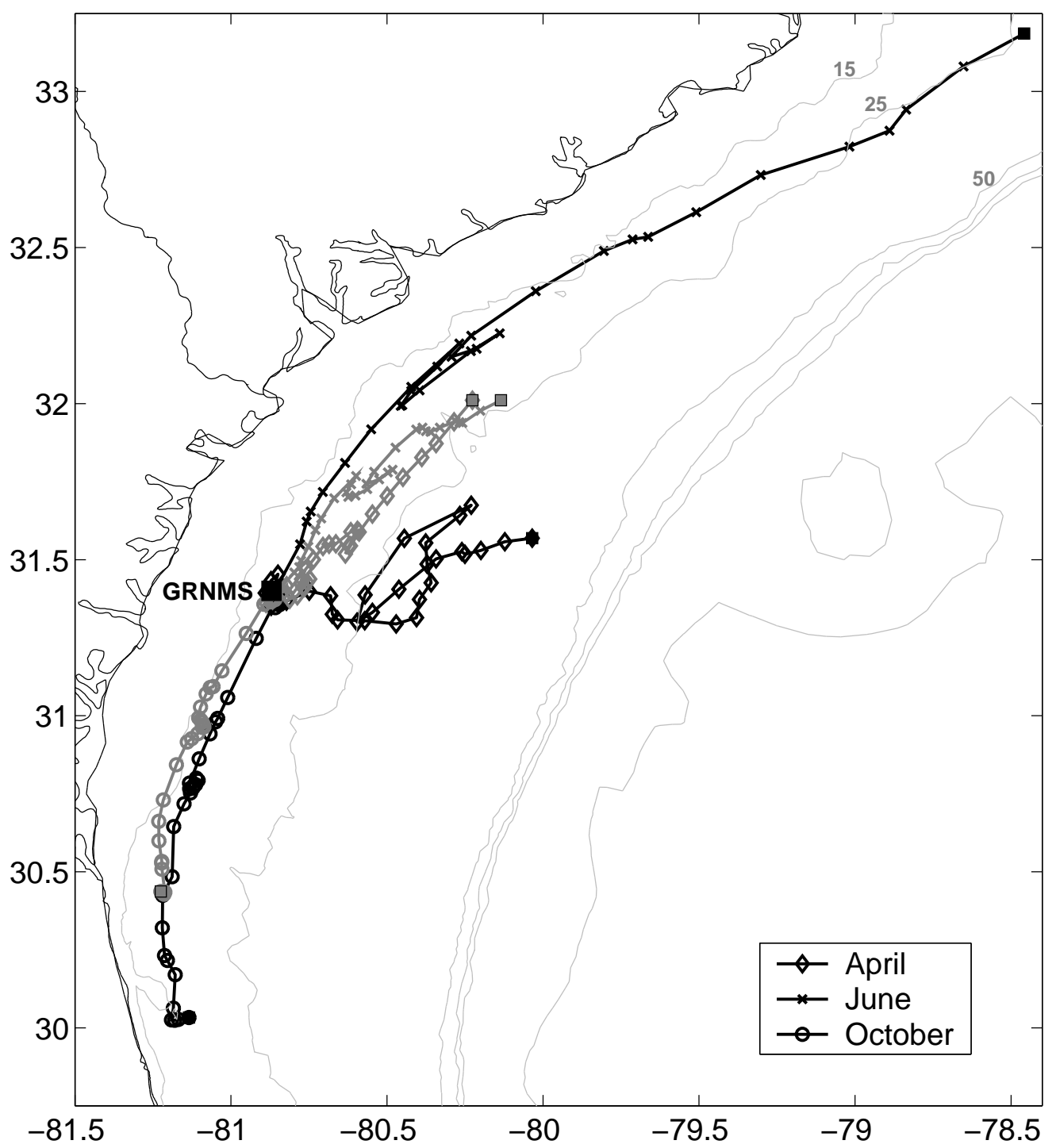

Fig. 6. Comparison of one of the model (grey) and observed (black) drifter tracks for each of the 2000 release periods. The axes are latitude in ${ }^{\circ} \mathrm{N}$ and longitude in ${ }^{\circ} \mathrm{W}$. 


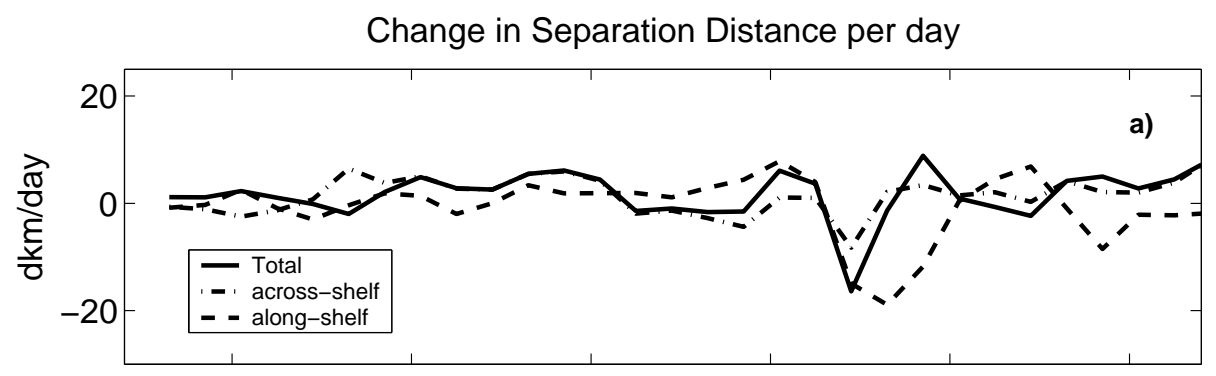

Model vs Grays Reef wind stress
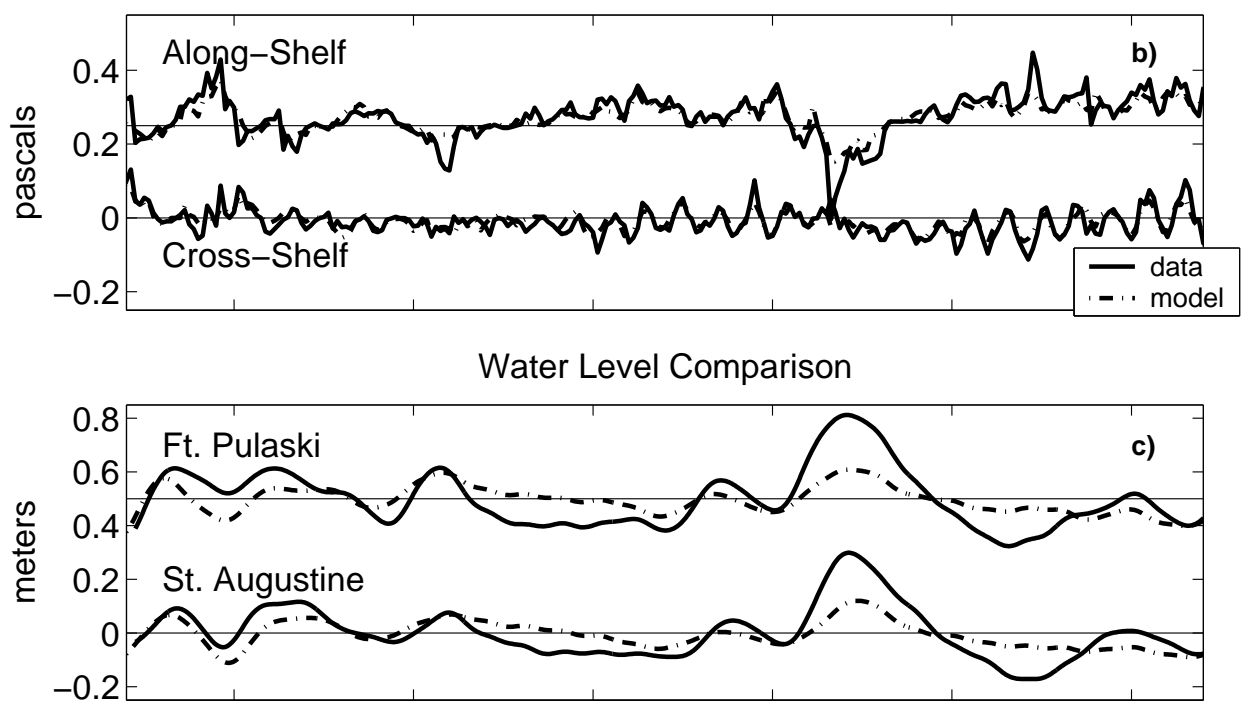

0 m Velocity Comparison

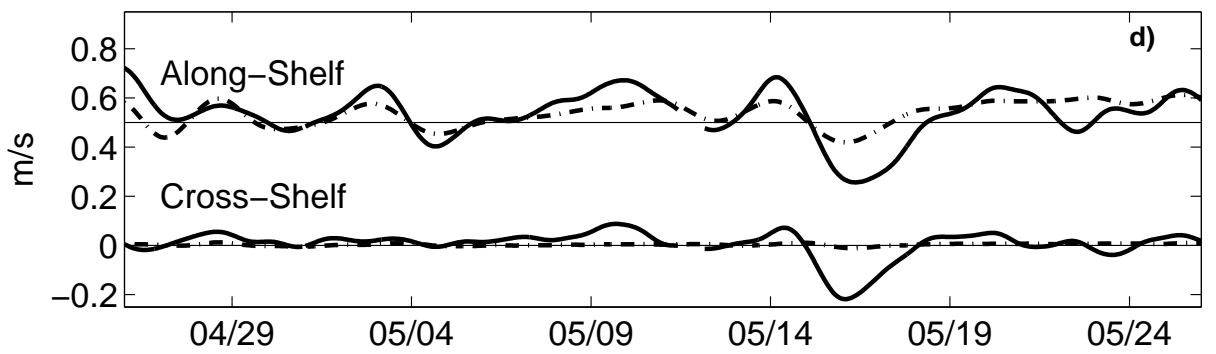

Fig. 7. a) Change in separation distance per day $\left(\mathrm{km} \mathrm{d}^{-1}\right)$ b) Comparison of observed and EDAS model along-(offset 0.15 Pascals) and cross-shelf wind stress. c) Comparison of model and observed demeaned water levels at Ft. Pulaski and St. Augustine (offset $0.5 \mathrm{~m}$ ) d) Comparison of model and observed along- (offset $0.25 \mathrm{~m} \mathrm{~s}^{-1}$ ) and cross-shelf velocities at R6. 
Change in Separation Distance per day

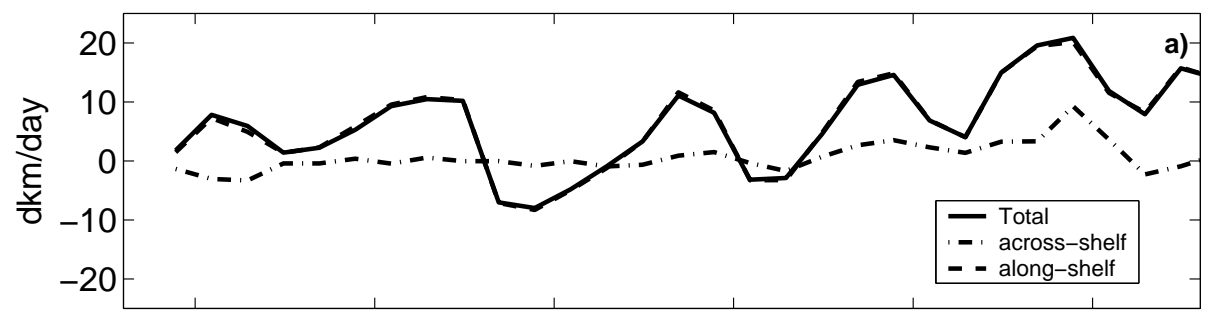

Model vs Grays Reef wind stress

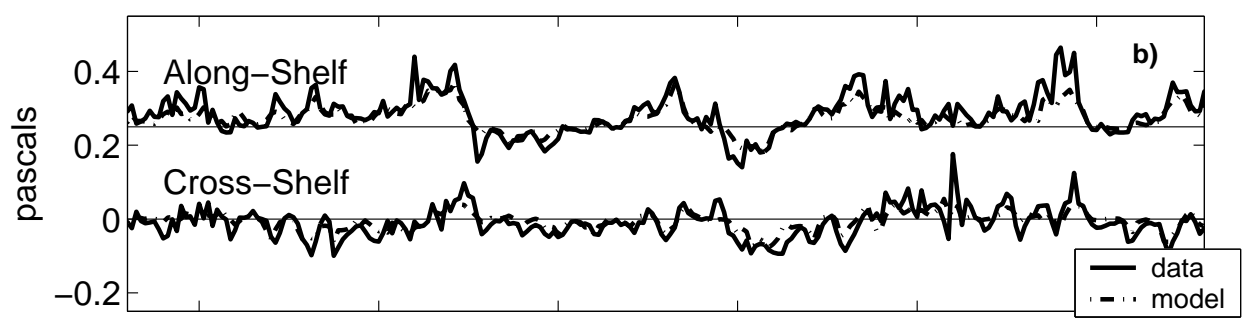

Water Level Comparison

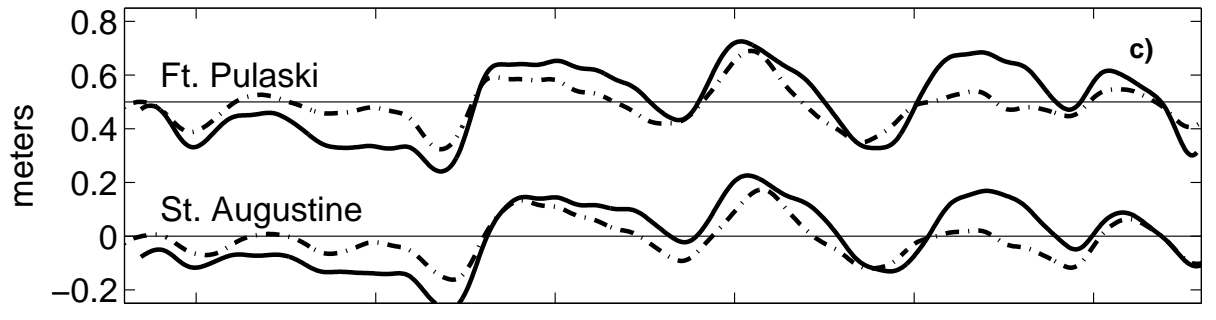

10 m Velocity Comparison

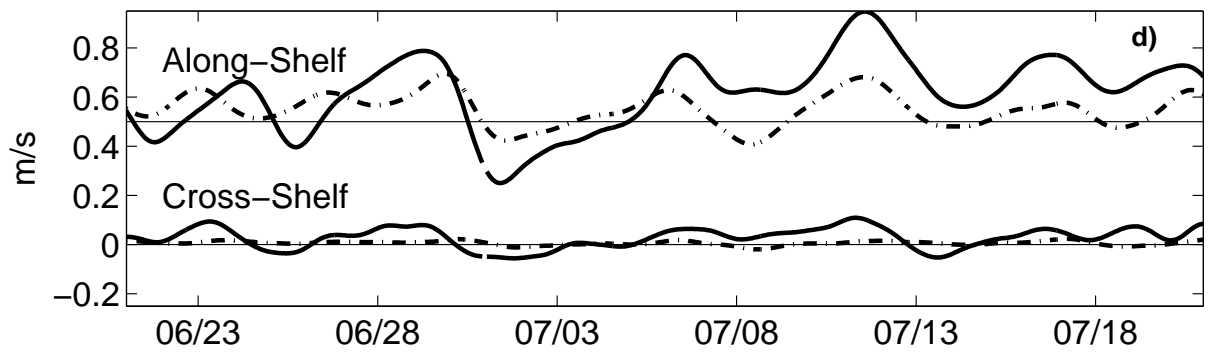

Fig. 8. Same as Figure 7 but for the June 2000 release period. 


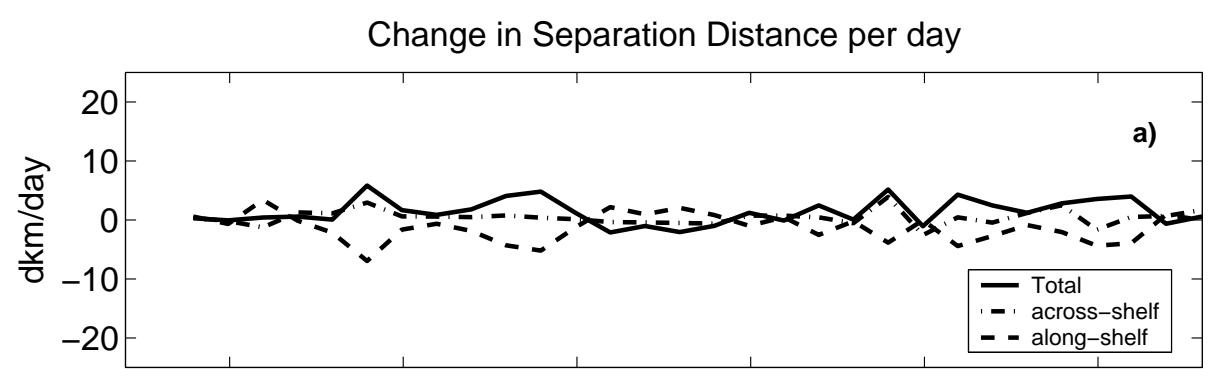

Model vs Grays Reef wind stress

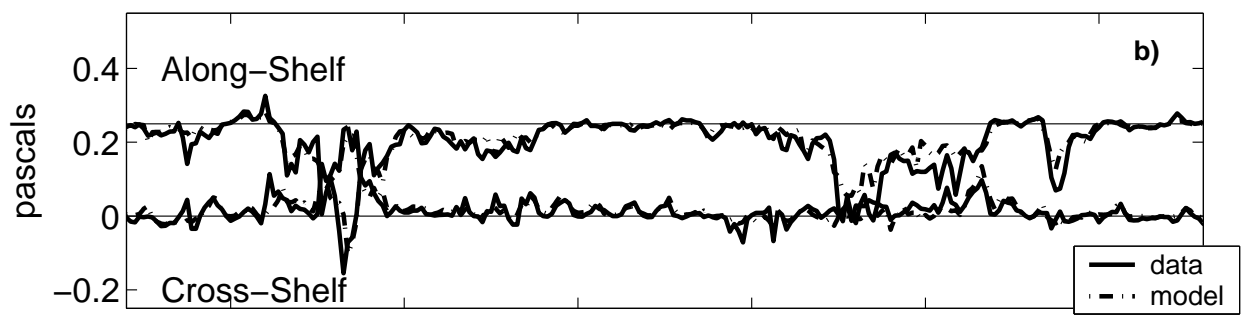

Water Level Comparison

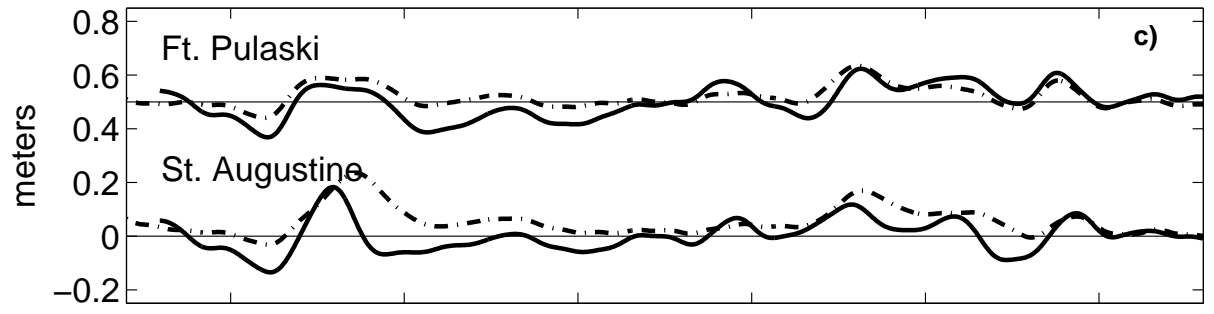

10 m Velocity Comparison

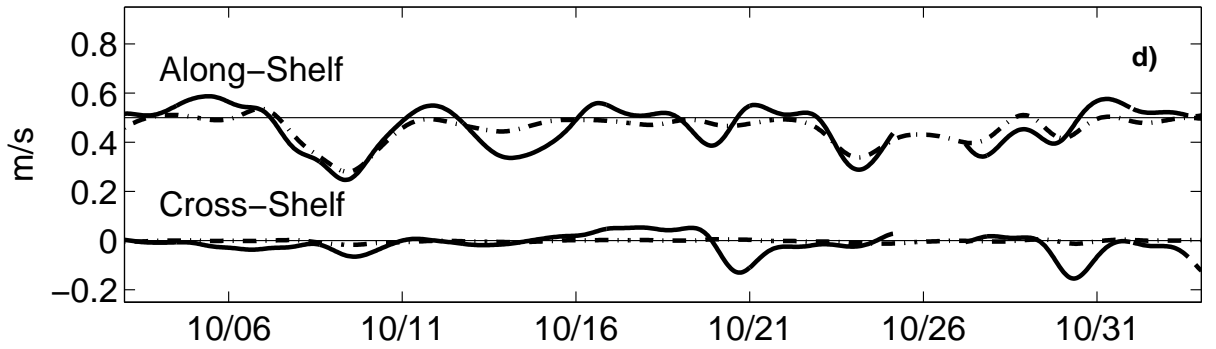

Fig. 9. Same as Figure 7 but for the October 2000 release period. 


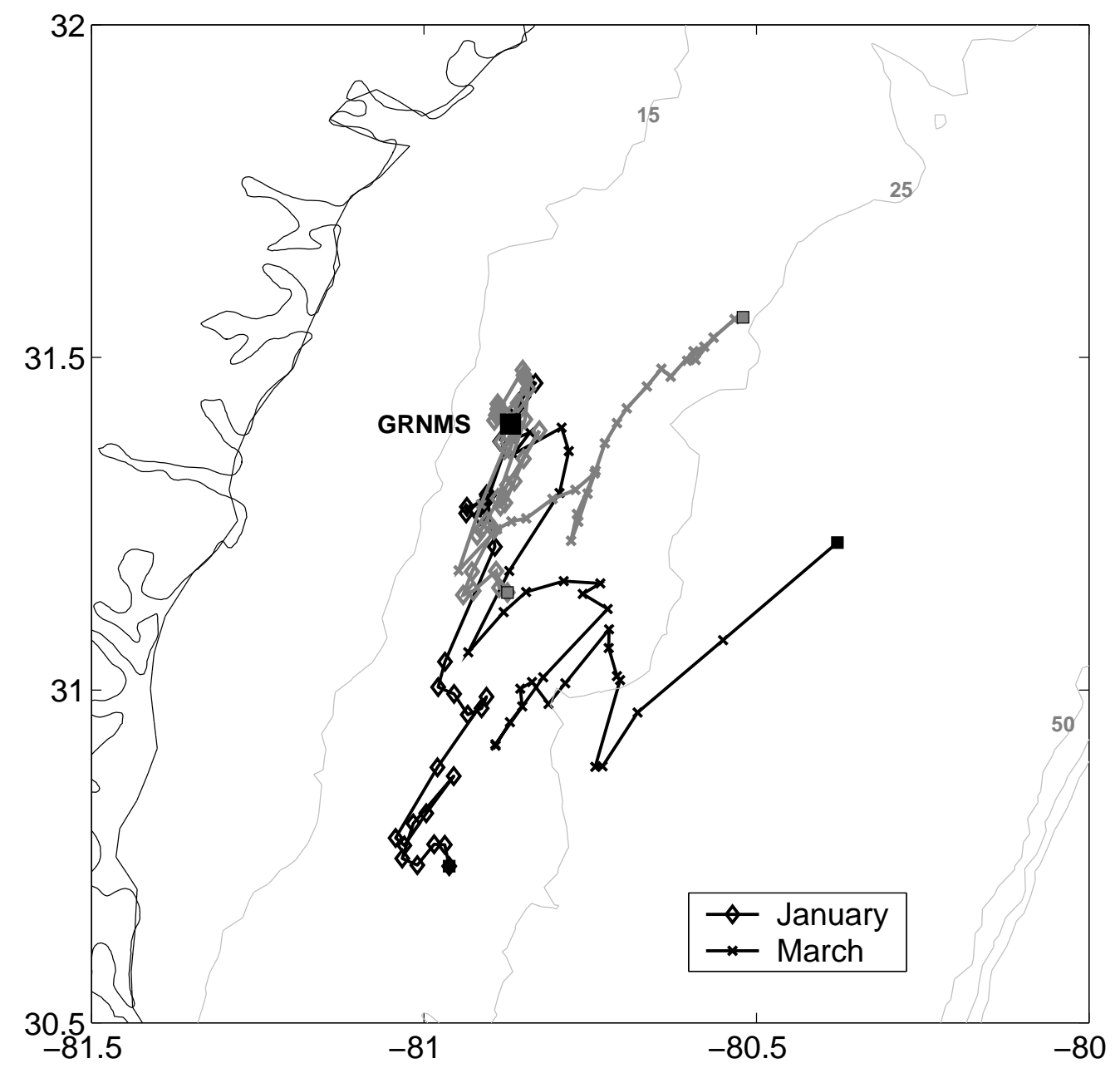

Fig. 10. Same as Figure 6 but for the January and March 2001 release periods. The axes are latitude in ${ }^{\circ} \mathrm{N}$ and longitude in ${ }^{\circ} \mathrm{W}$. 
Change in Separation Distance per day

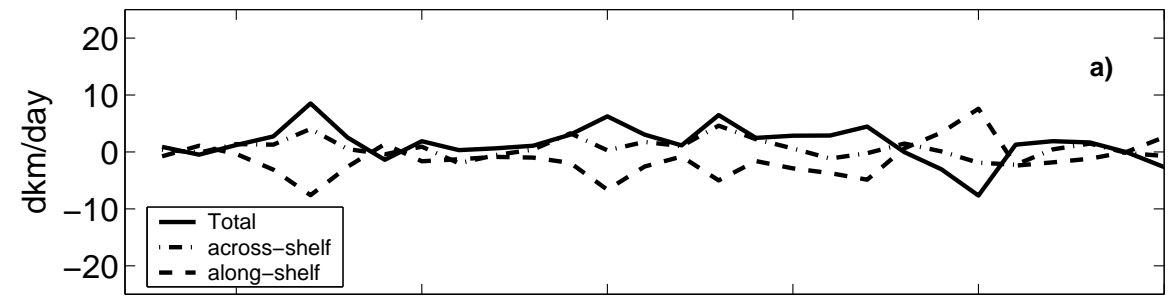

Model vs Grays Reef wind stress

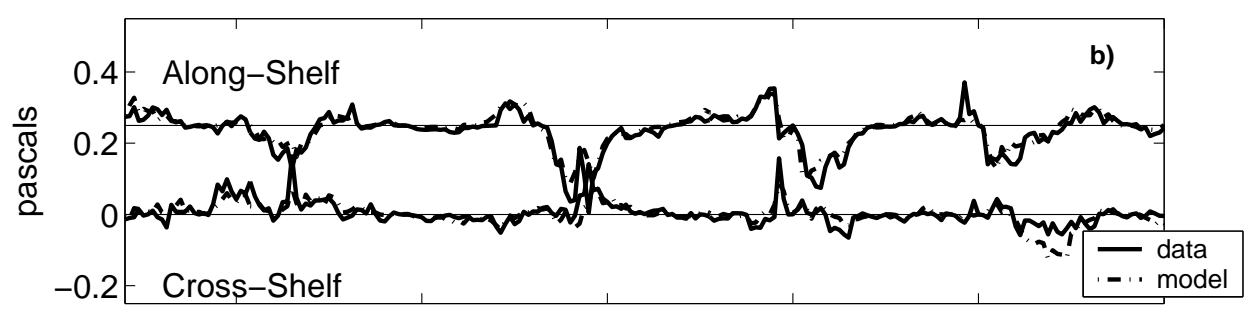

Water Level Comparison

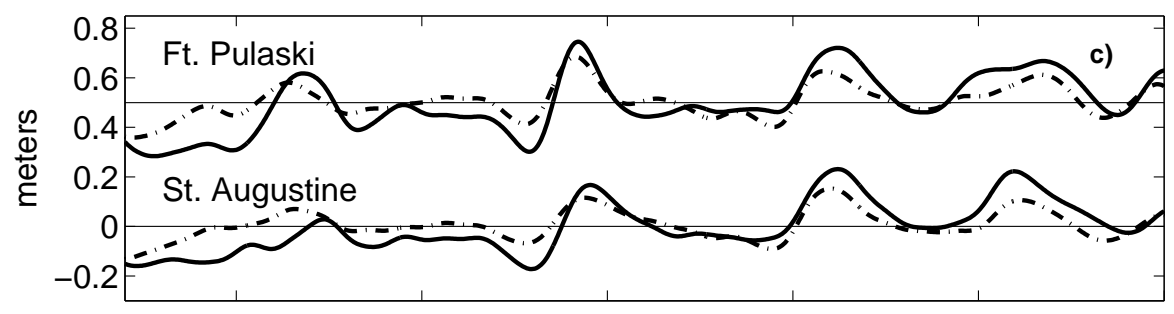

10 m Velocity Comparison

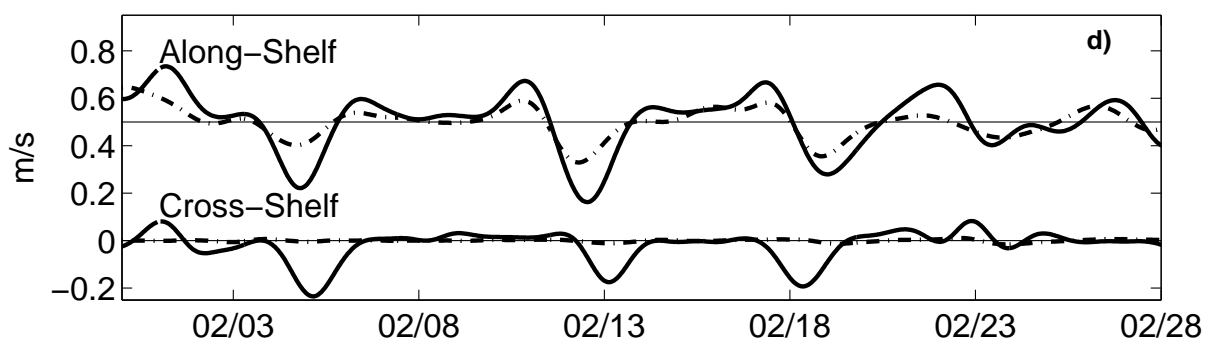

Fig. 11. Same as Figure 7 but for the January 2001 release period. 


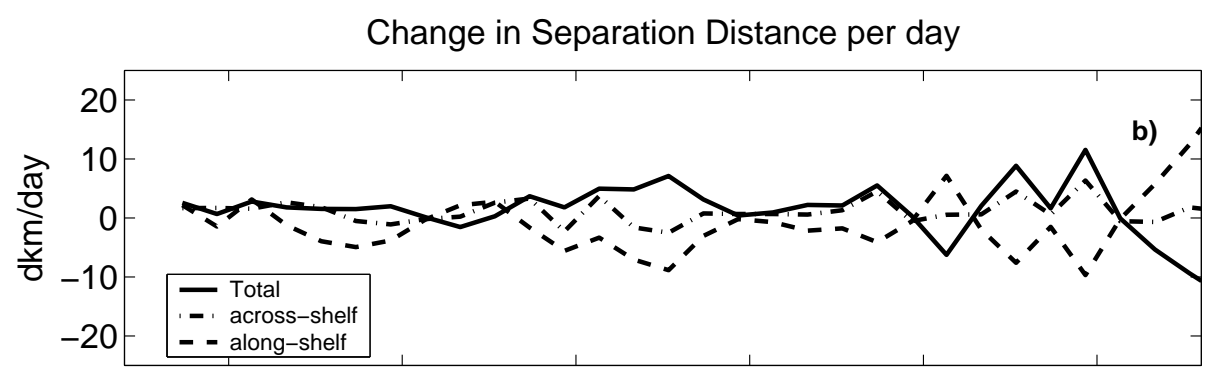

Model vs Grays Reef wind stress

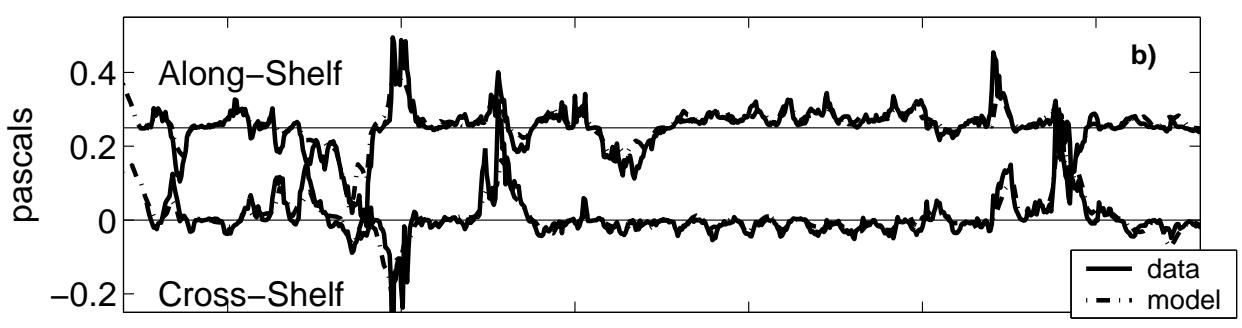

Water Level Comparison

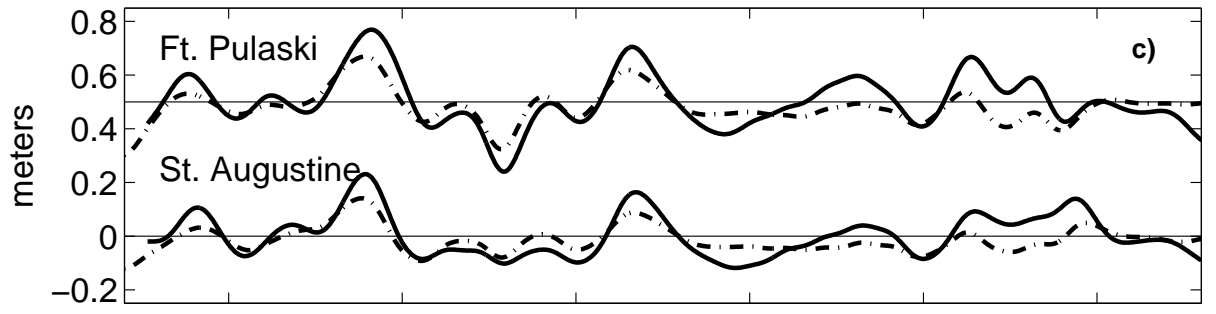

10 m Velocity Comparison

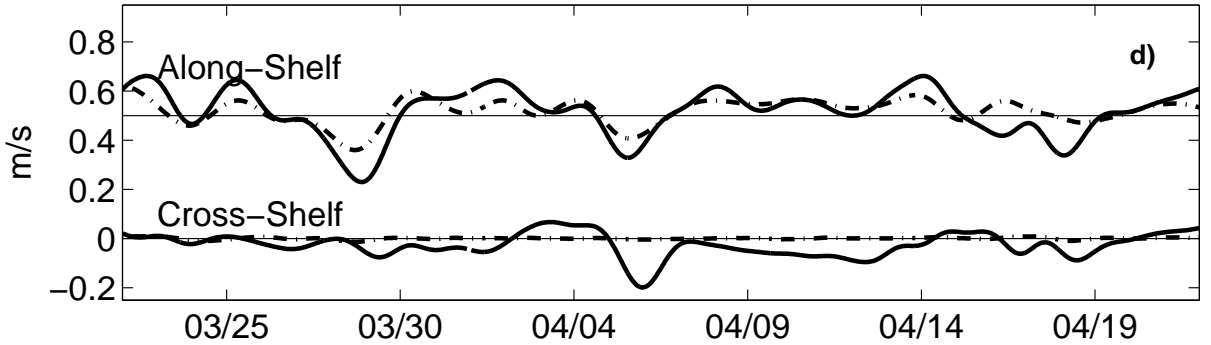

Fig. 12. Same as Figure 7 but for the March 2001 release period. 